\title{
Sediment routing from shelf to basin floor in the Quaternary Golo System of Eastern Corsica, France, western Mediterranean Sea
}

\author{
Sweet Michael L. 1, ${ }^{*}$, Gaillot Gwladys T. ${ }^{2}$, Jouet Gwenael ${ }^{3}$, Rittenour Tammy M. ${ }^{4}$, Toucanne Samuel \\ ${ }^{3}$, Marsset Tania ${ }^{3}$, Blum Michael D. ${ }^{5}$
}

${ }^{1}$ ExxonMobil Upstream Research Company, 22777 Springwoods Village Parkway, Spring, Texas

77389, USA

2 ExxonMobil Upstream Business Development Company, USA

3 Institute Français de Recherche L'Exploitation de la Mer, Géosciences Marines, F-29280 Plouzané, France

4 Department of Geology, Utah State University, 4505 Old Main Hall, Logan, Utah 84322, USA

5 Department of Geology, 1475 Jayhawk Blvd., University of Kansas, Kansas 66045, USA

* Corresponding author : Michael L. Sweet, email address :

\begin{abstract}
:
How and when sediment moves from shallow marine to deep-water environments is an important and poorly understood control on basin-scale sediment dispersal patterns, the evolution of continental margins, and hydrocarbon exploration in deep-water basins. The Golo River (Eastern Corsica, France), its delta, canyons, and fans provide a unique opportunity to study sediment routing from source to sink in a relatively compact depositional system. We studied this system using an array of high-frequency seismic data, multi-beam bathymetry, and five cores for lithology and age control.
\end{abstract}

Movement of sediment to deep water was controlled by interactions between the Golo River, the Golo Delta, and shelf-penetrating submarine canyons. Sediment moved to deep water when lobes of the Golo Delta prograded to the heads of these canyons, or when the Golo River itself flowed directly into one of them. Sand accumulated in canyons, deep-water channels, and submarine fans during glacial periods of low sea level, while mud was deposited throughout the slope, in the relatively short reach of leveedconfined channels, and in the mud-rich fringes around the sandy fans. During interglacial periods of high sea level, the basin was blanketed by mud-rich deposits up to $10 \mathrm{~m}$ thick interbedded with distinctive carbonate-rich sediments. Deposition rates in the basin ranged from $0.07 \mathrm{~m} / \mathrm{ka}$ to $0.59 \mathrm{~m} / \mathrm{ka}$ over the last $450 \mathrm{ka}$. Mud deposition rates remained relatively constant at $\mathrm{i} \ll 0.16 \mathrm{~m} / \mathrm{ka}$ during all time periods, while sand deposition only happened during glacial periods of low sea level with an average rate of $0.24 \mathrm{~m} / \mathrm{ka}$.

In addition to sea-level controls on sediment delivery, avulsions of the Golo River and its deltaic lobes preferentially routed sediment down either the North or South Golo canyons. Thus, while the larger, sequencescale architecture of the basin is controlled by allogenic sea level forcing, millennial-scale autogenic processes operating on the shelf and in deep water shaped the distribution of sand and mud, and the internal geometry of the deltas and submarine fans that they fed. While some aspects of the Golo system are characteristic of steep, tectonically active margins, others such as the nature of connections 
between rivers and shelf-penetrating submarine canyons are observed in most margins with active submarine fans regardless of their tectonic setting. 
New insights into deep-water depositional systems are coming from a growing body of

42 literature that describes the geometry and facies distribution observed from high-resolution

43 seismic, multi-beam bathymetry, and core data in Quaternary deep-water systems (e.g.,

44 Babonneau et al., 2002; Deptuk et al., 2008; Maier et al., 2012; Sylvester, 2012; Paull et al.,

45 2013; Jobe et al., 2015; Picot et al., 2016). These studies provide a richer understanding of three-

46 dimensional facies geometries relative to outcrops and enable deep-water systems to be more

47 clearly placed in the context of external controls such as climate, tectonic setting, sea level

48 change, and basin morphology as well as inherent autogenic processes.

49 This study examines the Golo system of eastern offshore Corsica using a relatively

50 closely spaced grid of high-resolution, multi-channel sparker seismic data (400 to $800 \mathrm{~m}$ 
51 spacing), multi-beam bathymetry, and lithology and chronological constraints from 5 long (up to

$52126 \mathrm{~m}$ ) cores to document facies distribution and sediment flux through a Quaternary system

53 from deltas to slope canyons and to submarine fans (Figures 1 and 2). The Corsica Trough was

54 chosen for this study because it is a compact basin where seismic data could be acquired across a

55 range of depositional environments from deltaic to deep-water fans in a depositional system that

56 was constrained by previous work. These seismic data allowed us to map sediment volumes in

575 depositional sequences spanning the last $\sim 50 \mathrm{ka}$. We utilized a variety of geochronological

58 tools $\left({ }^{14} \mathrm{C}\right.$, Optically Stimulated Luminescence (OSL), and $\delta^{18} \mathrm{O}$ curves) to date the timing of

59 sediment flux into the basin and to determine rates of sedimentation through multiple sea level

60 cycles.

61 The objectives of this study are:

62 1) Map and interpret the shape, distribution, and origin of sedimentary bodies.

63 2) Quantify how the mud and sand fractions of sediment loads are partitioned between shelf, 64 slope and deep-water environments.

65 3) Quantify how and when sediment moved from the shelf into deep water.

66 4) Examine the external controls on deep-water-fan growth.

\section{Corsica and the East Corsica Basin}

Corsica is a mountainous island in the western Mediterranean Sea $85 \mathrm{~km}$ wide and 180

$70 \mathrm{~km}$ long, with the highest peaks rising to an elevation of over $2700 \mathrm{~m}$. On the western margin of

71 the island the mountains come down to the coast and there is only a narrow coastal plain (Figure

72 1). Offshore, water depths rapidly fall off to over $2500 \mathrm{~m}$. In contrast, the eastern margin of the

73 island has a wider coastal plain (about $15 \mathrm{~km}$ ) that represents the alluvial plains and deltas of the 
74 Golo and Tavignano rivers (Figure 1). These rivers are short, high-gradient streams with flashy

75 discharges and high sediment yields that are capable of generating hyperpycnal flows when in

76 flood stage (Mulder and Maneaux, 1999). In our study area, sediment is primarily delivered by

77 the Golo River (Figure 1).

78 The present-day shelf ranges in width from 4 to $9 \mathrm{~km}$ within the limits of our study area,

79 and the strong, north-directed Tyrrhenian Current sweeps it clear of fine-grained Holocene

80 sediment (Astraldi and Gasparini, 1992; Pluquet, 2006). The shelf-slope break occurs at $-120 \mathrm{~m}$.

81 The continental slope leading to the south-plunging Corsica Trough is narrow with a gradient of

823 to 5 degrees, and water depths of over $900 \mathrm{~m}$ (Figure 1). The eastern side of the Corsica

83 Trough is formed by a structural high, the Pianosa Ridge, which is steeper than the Corsica side

84 of the Trough. The slope here dips westward at 3.5 to 7.5 degrees (Deptuck et al., 2008). Most of

85 the Pianosa Ridge is submerged with the small island of Elba being the largest nearby landmass

86 (Figure 1). While there are no canyons on the eastern side of the basin, seismic mapping by

87 Miramontes et al (2016a and b) shows evidence for slumps and slides, as well as extensive

88 contourite deposits. Our seismic mapping, discussed below, suggests there is little sediment

89 contribution from the Pianosa Ridge to the Corsica Trough, with the exception of some localized

90 debris flow deposits.

91 More broadly, the island of Corsica and the adjacent Corsica Trough are part of a backarc

92 basin associated with the early Miocene opening of the Tyrrhenian Sea (Jolivet et al., 1998). The

93 basin contains up to $10 \mathrm{~km}$ of Pleistocene to Miocene-age syn-rift and post-rift sediments

94 (Mauffert et al, 1999). The other major factor that affected the Neogene configuration of this

95 area was the Miocene evaporation of the Mediterranean which caused a dramatic regrading of

96 rivers and incision of canyons all along the Mediterranean coastline with Corsica being no 
97 exception (Hsu, 1973; Ryan, 2009). The Messinian erosion surface can be seen on some of our

98 seismic data, but it is well below the maximum depth of investigation for this study.

\section{Previous Work on Golo/Corsica Basin}

The first seismic data shot across the Corsica Trough (Gabin, 1972) showed the general

102 configuration of the basin. Seismic and piston-core data published by Stanley et al. (1980) more

103 thoroughly characterized the Golo fans and provided insight into the near-surface Quaternary

104 sediment types and their ages. Bellaiche et al. (1994) published a detailed bathymetric map of the

105 area covering the North and South Golo canyons and the North and South Golo fans. Gervais et

106 al. (2004) and Gervais et al. (2006) mapped major depositional elements of the North and South

107 Golo canyons, as well as their associated channels, levees and lobe complexes from $>1000 \mathrm{~km}$ of

108 sparker seismic data and 35 shallow cores. In addition, they provided a stratigraphic framework

109 for the last $40 \mathrm{ka}$. Deptuck et al. (2008) focused on the youngest deposits, primarily from the

110 submarine fans, using $1300 \mathrm{~km}$ of ultra-high resolution, deep-towed seismic boomer profiles.

111 Sømme et al. (2011) took a source-to-sink approach to the Golo system. They mapped

112 and dated the Upper Quaternary onshore deposits of the Golo River, calculated sediment fluxes

113 and used the stratigraphic framework of Deptuck et al. (2008) to analyze the controls on

114 sediment routing for the last $60 \mathrm{ka}$. Their study interpreted a nonlinear relationship between

115 onshore and offshore depositional environments with potential temporary storage and release of

116 sediment on the shelf. Deptuck et al. (2008) and Sømme et al. (2011) based their sediment flux

117 calculations on an age model based on seismic mapping calibrated to ${ }^{14} \mathrm{C}$ ages from shallow

118 cores. Calves et al. (2013) pursued a similar source-to-sink analysis using very high-resolution

119 sub-bottom profiler and high-resolution sparker data. Their age model was based largely on 
120 comparison of $\delta^{18} \mathrm{O}$ and XRF-Ca intensity curves with global standards, and resulted in an age

121 model with older maximum ages (120 ka with up to $18 \mathrm{ka}$ discrepancy) than the age model that

122 Deptuck et al. (2008) and Sømme et al. (2011) had used. With their method, Calves et al. (2013)

123 were able to provide age estimates for a slightly deeper portion of the fan, which allowed them to

124 run a source-to-sink analysis for the last $130 \mathrm{ka}$ (i.e., over a full sea-level cycle). Calves et al.

125 (2013) highlighted a potential mismatch between the volume of sediments deposited offshore

126 and the predicted denudation rates from long-term averages. Toucanne et al. (2015) used the 126

127 m-long GDEC-4 core to provide a chronostratigraphic framework for the East Corsica margin

128 over the last ca. $450 \mathrm{ka}$, calibrated to seismic data. They interpreted their continuous, high-

129 resolution paleo-climatic record to reveal a close coupling between river runoff and glacial-

130 interglacial climate changes. Forzoni et al. (2015) studied sediment fluxes in the Golo River

131 drainage using OSL dating and numerical models compared to the sediment yield derived from

132 volumes and ages in the submarine fans from both Sømme et al. (2011) and Calves et al. (2013).

133 They interpreted mismatches to represent episodes of sediment storage within the catchment, and

134 lag times in sediment transport from the catchment area, as controlled by climate, sea-level

135 changes and local geomorphic thresholds. Miramontes et al. (2016b) related geostrophic

136 circulation through the Corsica Trough to the deposition of thick drift deposits along the eastern

137 margin of the trough.

139 METHODS AND DATA

140 Seismic Data and Seismic Interpretation

141 Seismic and bathymetric data were gathered in June of 2008 by the IFREMER research

142 vessel Le Suroît, as part of a joint research consortia between IFREMER, ExxonMobil and Total. 
143 Le Suroit acquired $2950 \mathrm{~km}$ of multi-channel, sparker seismic data, referred to herein as the 144 Sigolo survey (Savoye, 2008), along with very high-resolution, sub-bottom profiler (CHIRP 145 mode) seismic data (Figure 2). Seismic and bathymetry data could only be acquired for that part 146 of the outer and middle shelf where water depths exceeded $30 \mathrm{~m}$ due to the draft of the Le Suroit. 147 Sigolo data were post-stack time-migrated and have a frequency content ranging from 148130 to $750 \mathrm{~Hz}$ with a vertical resolution of 2 to $4 \mathrm{~m}$. Line spacing was on a variable $800 \mathrm{~m}$ to 400 149 m grid, with more closely spaced lines acquired in the vicinity of the Golo canyons and in the 150 channel to lobe transition of the South Golo Fan (Figure 2). Seismic data were reprocessed after 151 the cruise to enhance imaging below the modern-day continental shelf and reduce the impact of 152 multiples. Wells were tied to the reprocessed seismic data using a constant velocity of $1600 \mathrm{~m} / \mathrm{s}$ 153 below the mudline for the time/depth conversion. This velocity produced a good tie between 154 marls observed in core and high amplitude seismic reflections observed in the seismic data over 155 the basin. This character tie is more uncertain on the shelf were sediments are uniformly sandy 156 and could have higher seismic velocities due to compaction and cementation.

157 Seismic interpretation was done on a workstation using Petrel ${ }^{\mathrm{TM}}$ software. While there is 158 some controversy about how apply sequence stratigraphic techniques to mapping deep water 159 deposits (i.e., Neal and Abreu, 2009; Catuneanu, 2019), the following approach helped us to 160 interpret these data. We first looked for extensive surfaces that showed stratal terminations 161 (downlap, truncation and onlap). Following Mitchum (1985) downlap surfaces that could be 162 correlated across the study area are interpreted to represent submarine fan deposits resting on a 163 sequence boundary. Our definition of sequence boundaries follows Posamentier and Vail (1988).

164 We then identified the first basin-wide, high-amplitude, continuous seismic reflection that draped 165 the underlying stratigraphy (Figure 3). These surfaces were termed flooding surfaces. Surfaces 
166 are assigned numbers, with the lowest numbers being the oldest, and we use the prefixes FS for

167 flooding surfaces and SB for sequence boundaries. To begin mapping, a series of looped and tied

168 seismic sections were constructed, starting in the deep basin. In some cases, reflections mapped

169 in the deep basin could be traced up the slope and onto the shelf, but many are lost due to

170 thinning or onlap in the upper slope. Furthermore, submarine canyons on the slope and the larger

171 submarine channels are a challenge to correlate across. In most cases it is impossible to

172 accurately correlate seismic events within the channel-fill deposits to a reflection outside the

173 channel or canyon because of the chaotic character of the seismic facies in the channel or

174 canyon. However, by tracing lines around the canyons it is possible to identify the same

175 reflection on both sides of the canyon and in that way develop a consistent stratigraphic

176 framework. We used these basin-wide surfaces to define depositional sequences bounded at the

177 base and top by sequence boundaries. In terms of mapping and understanding the distribution of

178 lithofacies we found it more useful to map systems tracts (Posamentier et al, 1988) than

179 sequences. The lowstand systems tract being defined by sediments between the sequence

180 boundary and the flooding surface (Van Wagoner et al., 1990). As we were not able to

181 consistently map the maximum flooding surface that separates the highstand from transgressive

182 systems tracts we lumped them together (i.e., the sediments between the flooding surface and the

183 overlying sequence boundary) for mapping purposes.

184 The approach of identifying surfaces marked by downlap, onlap, reflection terminations

185 and draping high-amplitude continuous seismic facies was applied sequentially to smaller and

186 smaller scale stratigraphic units. However, our more detailed mapping was restricted to the

187 deep-water basin due to the numerous multiples that underlie the shelf part of the succession, and

188 was performed at finer stratigraphic levels only in the youngest shelf deposits. 
190 Core Data

191 In September 2009 a coring program, the Golodrill survey, was undertaken in

192 collaboration with IFREMER, Total, ExxonMobil and Fugro N. V. using the Fugro drillship $R / V$

193 Bavenit (Jouet, 2018). Five cores ranging in length from 65 to $126 \mathrm{~m}$ were collected on a shelf-

194 to-basin transect along the South Golo Canyon and Fan (Figure 2). Overall the coring program

195 was extremely successful. High recoveries were expected in fine-grained intervals, yet they

196 remained high within the sand- and gravel-rich intervals as well, such that total recovery ranged

197 from 75 to $93 \%$ (Table 1 ).

198 Cores were analyzed and described at IFREMER's lab in Brest, France where measurements

199 were made of total natural gamma ray radioactivity, laser particle size analysis as well as

200 calcimetry. Oxygen and carbon isotopes from benthic and planktic foraminifera were done at the

201 LSCE (Toucanne et al., 2015). Cores were also sampled for Optically Stimulated Luminescence

202 (OSL) and ${ }^{14} \mathrm{C}$ dating.

203

204 Lithfacies from core

205 Cores GDEC-1 and GDEC-3 were collected on the shelf to obtain data on the lithology

206 and age of shelf deposits. GDEC-1 was drilled in $116 \mathrm{~m}$ of water on seismic line Sigolo-034b

207 near the shelf-slope break where initial interpretation suggested the occurrence of delta lobes

208 attached to the canyon head (Figures 2 and Figure 4). GDEC-1 penetrated $75.2 \mathrm{~m}$ below the sea

209 floor (mbsf; Table 1), and encountered a range of grain sizes from silt and clay to gravel. The

210 lower $18 \mathrm{~m}$ is composed of gravel with carbonate cemented intervals, whereas the interval from

$21157-22$ mbsf is dominated by interbedded fine to medium sand and silty clay. A sharp-based, 
212 fining-upward unit composed of gravel at the base and silty-clay at the top occurred between 22

213 mbsf and $11 \mathrm{mbsf}$, and the upper $11 \mathrm{~m}$ is comprised of interbedded medium to coarse sand and

214 silty clay (Figure 5). GDEC-3 was drilled in $68 \mathrm{~m}$ of water at the intersection of seismic lines

215 Sigolo-034b and Sigolo-066 where initial interpretations suggested the presence of an isolated

216 delta lobe overlying the fill of a paleo-incised valley (Figures 2 and 4). GDEC-3 penetrated to a

217 depth of $64.8 \mathrm{mbsf}$ (Table 1), where carbonate-cemented coarse sand is encountered (Figure 5).

218 Most of the cored interval consists of very fine to coarse sand. From 38 mbsf to the surface there

219 is an overall upward coarsening, starting in silt and ending in coarse sand at the sea floor. A thick

220 conglomerate was found at $11 \mathrm{~m}$. Based on their location, seismic and core facies, GEDEC-1 and

221 GDEC-3 are interpreted to represent the deposits of prograding delta lobes and paleo-valley fills.

222 GDEC-4 was drilled on the mid to lower slope, in $491 \mathrm{~m}$ of water to a depth of 125.7

223 mbsf at the intersection of seismic lines Sigolo-085 and Sigolo-036 (Figure 6). The objective was

224 to sample facies well removed from the submarine canyons in an area of relatively slow and

225 continuous deposition to development a detailed $\delta^{18} \mathrm{O}$ record that could be used for dating (see

226 Toucanne et al., 2015). Aside from a few thin silt beds the core is primarily composed of silty

227 clay and carbonate-rich silty clay, and included 9 marl layers that ranged in thickness from 1 to 8

$228 \mathrm{~m}$ (Figure 5).

229 GDEC-6 and GDEC-8 were drilled on the submarine fan at depths of $826 \mathrm{~m}$ and $631 \mathrm{~m}$

230 respectively. GDEC-6 was collected at the intersection of the Sigolo-058 and Sigolo-004

231 seismic lines, and drilled to a depth $80.2 \mathrm{mbsf}$ (Figures 2 and 7). This core was collected where

232 seismic facies suggested the presence of sand-rich, lobe-margin deposits within two adjacent

233 lobes of the South Golo Fan, high-amplitude continuous reflections between them that were most

234 likely muds, and underlying high-amplitude continuous seismic facies that we hoped to use for 
235 age control. The upper $50 \mathrm{~m}$ of the core is very sand-rich with grains of up to granule size. These

236 sands show normal grading and other sedimentary structures consistent with deposition from

237 turbidity currents. Unfortunately, due to time constraints the core could not be drilled deep

238 enough to encounter the high-amplitude continuous seismic facies as planned, although a thick

239 section of shale was recovered from 50 mbsf to 80 mbsf. This interval contained 3 marls ranging

240 from 0.5 to $1.5 \mathrm{~m}$ in thickness. GDEC-8 was drilled at the crossing of seismic lines Sigolo-048

241 and Sigolo-007 to a depth of $108.8 \mathrm{mbsf}$ (Figure 2). The drilling objectives of this location were

242 to sample a proximal levee visible on bathymetric data, as well seismic facies interpreted as a

243 channel-lobe transition (Figure 8). Core facies and gamma-ray data show that the proximal levee

244 is muddier than expected, with slightly more silty layers at its base. Channel-lobe transition

245 deposits consists largely of coarse sand and gravel interbedded with carbonate-rich draping muds

246 (Figure 5). These sands show normal grading and other sedimentary structures consistent with

247 deposition from turbidity currents

\section{Chronological Control}

250 We sampled cores for ${ }^{14} \mathrm{C}$ and OSL dating, and oxygen isotope analyses. Benthic

251 foraminifera and ostracod assemblages described from the GDEC-4 core, with results reported in

252 Minto'o et al. (2016).

253 Seventy samples for AMS radiocarbon dating were obtained from macrofossils (Pecten

254 and other bivalves, Turritella and other gastropods), woody material and foraminifera in the 5

255 cores, and were used to build our age model for the last 40 ka (Figure 5, Appendix 1). Samples

256 were analyzed by the Poznań Radiocarbon Laboratory, and lab results were corrected for a

257 marine reservoir effect of 400 yrs, except for those from the period 15-17 ka, for which a 
correction of 800 yrs was applied (Siani et al., 2001). Radiocarbon ages were calibrated to

259 calendar years using CALIB Rev 7.0.0 (Stuiver and Reimer, 1993) and the IntCal13 calibration

260 curve (Reimer et al., 2009).

261 Twenty-two samples were collected for OSL dating from sands in the GDEC-1, GDEC-3,

262 GDEC- 6 and GDEC-8 cores (Appendix 2). Although widely used in fluvial and other sand-

263 dominated environments on land, OSL techniques have rarely been applied to dating deep water

264 deposits. We found that this technique gave excellent results and allowed direct dating of sands

265 as old as $127 \mathrm{ka}$. Sample analyses were performed in the Utah State University (USU) OSL Lab.

266 All samples were opened and processed under dim amber safelight conditions within the lab.

267 Sample processing followed standard procedures involving sieving, gravity separation and acid

268 treatments with $\mathrm{HCl}$ and $\mathrm{HF}$ to isolate the quartz component of a narrow grain-size range,

269 usually $90-150 \mu \mathrm{m}$. The purity of the samples was checked by measurement with infra-red

270 stimulation to detect the presence of feldspar. Sample processing procedures follow those

271 outlined in Aitken (1998) and described in Rittenour et al. (2003, 2005). The USU lab follows

272 the latest single-aliquot regenerative-dose (SAR) procedures for dating quartz sand (Murray and

273 Wintle 2000, 2003; Wintle and Murray 2006).

274 Stable carbon and oxygen isotopes were measured from planktic and benthic

275 foraminifera. ${ }^{18} \mathrm{O} /{ }^{16} \mathrm{O}$ and ${ }^{13} \mathrm{C} /{ }^{12} \mathrm{C}$ ratios $\left(\delta^{18} \mathrm{O}\right.$ and $\delta{ }^{13} \mathrm{C}$ respectively, expressed in \%o versus

276 Vienna Pee-Dee Belemnite, VPDB) were measured at LSCE (Gif-sur-Yvette, France) on

277 Finnigan $\Delta+$, and OPTIMA and Elementar Isoprime GV mass spectrometers. VPDB is defined

278 with respect to NBS-19 calcite standard $\left(\delta^{18} \mathrm{O}=-2.20 \%\right.$ and $\left.\delta \mathrm{C}^{13} \mathrm{C}=+1.95 \%\right)$. The mean

279 external reproducibility $(1 \sigma)$ of carbonate standards is $\pm 0.05 \%$ for $\delta^{18} \mathrm{O}$ and $\pm 0.03 \%$ for $\delta^{13} \mathrm{C}$.

280 Measured NBS-19 $\delta^{18} \mathrm{O}$ is $-23.3 \pm 0.15 \%$ VPDB. The samples were cleaned in a methanol 
281 ultrasonic bath for a few seconds and roasted under vacuum at $380^{\circ} \mathrm{C}$ for $45 \mathrm{~min}$ prior to 282 analysis, in order to eliminate impurities (Duplessy, 1978). Oxygen-isotope data were recorded 283 from benthic foraminifera sampled in the GDEC-4, GDEC-6 and GDEC-8 cores (Figure 9): data 284 from the GDEC-4 core was especially important because it had the most complete sampling of 285 material for stable isotope analysis, and our seismic mapping indicated that it was in an area of 286 relatively continuous sedimentation. The $\delta^{18} \mathrm{O}$ data provided age estimates for mapped seismic 287 surfaces by determining where these surfaces intersect the $\delta^{18} \mathrm{O}$ curve in the GDEC- 4 core, and 288 then matching the GDEC-4 $\delta^{18} \mathrm{O}$ curves to the global stacked $\delta^{18} \mathrm{O}$ curves of Lisiecki and Raymo 289 (2005). Oxygen isotope curves from GDEC-6 and GDEC-8 were not complete enough and too

290 disturbed by thick gravity flow deposits to be reliable for $\delta^{18} \mathrm{O}$ analyses. A more detailed analysis 291 of isotope data from the GDEC- 4 core that emphasises climatic change is found in Toucanne et 292 al. (2015).

\section{MAPPING AND DATING SEISMIC HORIZONS}

Ten regional seismic horizons were dated. ${ }^{14} \mathrm{C}$ provided reliable ages back to ca. $48 \mathrm{ka}$, 296 OSL back to $127 \mathrm{ka}$, and matching $\delta^{18} \mathrm{O}$ curves gave age control back to $478 \mathrm{ka}$ (Figures 5, 9 and 297 10). The GDEC-4 core was particularly important for surfaces older than 91 ka because it has a 298 very complete $\delta^{18} \mathrm{O}$ record that correlates well to the Lisiecki and Raymo (2005) global, stacked, 299 oxygen-isotope curves (Figure 9). In the GDEC-4 core, 9 thick marls were observed. These 300 marls could be correlated to marls in the other cores from the basin and were numbered 1 301 through 9 with 1 the youngest and 9 the oldest (Figure 5). They are interpreted to indicate 302 reduced clastic sedimentary input into the basin, similar to the carbonate-rich sediments that are 303 currently being deposited on abandoned parts of the South Golo Fan. These marls have depleted 
$304 \delta^{18} \mathrm{O}$ values that correlate to the episodes of depleted $\delta^{18} \mathrm{O}$ in the global stacked $\delta^{18} \mathrm{O}$ curves of 305 Lisiecki and Raymo (2005), hence penetration of these marls in the GDEC-4 core allows us to

306 provide age estimates for our deeper seismic horizons. These marl-rich horizons correspond to

307 very continuous, high-amplitude reflections with strong impedance contrasts, relative to the other

308 continuous seismic facies that have been tied to marl-free mudstones (Figure 6). The high

309 impedance contrast between marls and other sediments reflects their higher carbonate content,

310 lower porosity and higher density relative to the purely siliciclastic muds (e.g. Fig, 6).

311 There are limitations and uncertainties with our age model because GDEC-4 was the only

312 core that yielded a complete $\delta^{18} \mathrm{O}$ curve. In most cases, specific $\delta^{18} \mathrm{O}$ peaks did not directly

313 coincide with our seismic horizons, so we constrained seismic horizons by bracketing with older

314 and younger $\delta^{18} \mathrm{O}$ markers. Moreover, the majority of our chronological constraints are

315 internally consistent with each other, and with the seismic data (Figure 10). There were some

316 divergences between dating techniques, for example, in the case of the $1100 \mathrm{FS}$ and $1100 \mathrm{SB}$,

317 OSL ages from sands were younger than the age estimates obtained from $\delta^{18} \mathrm{O}$ data from

318 overlying marls. OSL ages in this case may represent minimum ages for the deposition of the

319 host sediment that was sampled.

320 SEDIMENT DISPERSAL THROUGH TIME

321 While we mapped older sequences below core control this paper will only describe the 322 intervals for which we had core and seismic control. The oldest of these is bounded by the 700 323 and 800 sequence boundaries. The lowstand systems tract deposits are bounded the $700 \mathrm{SB}$ and 324 the $700 \mathrm{FS}$ (Figures 6 and 10). The $700 \mathrm{SB}$ overlies a depletion spike on the $\delta^{18} \mathrm{O}$ curves that we 325 associate with the MIS-12 sea-level lowstand at ca. $450 \mathrm{ka}$, when sea level was at $-130 \mathrm{~m}$ relative 326 to present (Spratt and Lisiecki, 2016). We therefore interpret the downlapping seismic facies and 
327 fan-shaped isopach map pattern of this interval within the deep basin to represent a sand-rich

328 submarine fan deposited during MIS 12. The isochron map of this interval suggests the presence

329 of one large fan fed by the merging of input from both the North and South Golo canyons

330 (Figure 11).

331 The transgressive and highstand systems tract deposits between the $700 \mathrm{FS}$ and the 800

332 SB average $\sim 8 \mathrm{~m}$ in thickness across the study area and are composed of high-amplitude,

333 continuous seismic facies that are mud-rich with locally high carbonate content in the GDEC-4

334 core (Figure 6). We interpret these deposits to represent the MIS 11 interglacial.

335 The next overlying sequence is bounded by the $800 \mathrm{SB}$ and $900 \mathrm{SB}$. The lowstand

336 systems tract deposits between the $800 \mathrm{SB}$ and $800 \mathrm{FS}$, are poorly constrained by $\delta^{18} \mathrm{O}$ curves but

337 falls between horizons with age estimates of ca. 340 and $375 \mathrm{ka}$. The Waelbroeck et al. (2002)

338 sea-level curve places the MIS 10 glacial period of low sea level at -120 m relative to present,

339 between ca. 337 and $374 \mathrm{ka}$ (Figure 10). We therefore interpret fan deposits above the $800 \mathrm{SB}$ to

340 represent the MIS 10 glacial period, and the $800 \mathrm{FS}$ to represent the beginning of the MIS 9

341 interglacial period. An isopach map of the lowstand systems tract deposits between the $800 \mathrm{SB}$

342 and the 800 FS shows two lobe-shaped sediment thicks, one associated with the North Golo

343 Canyon and one with the South Golo Canyon (Figure 11).

344 The GDEC-4 oxygen-isotope curve suggests that the fine-grained sediments between the

$345800 \mathrm{FS}$ and the $900 \mathrm{SB}$, which include marl 8, were deposited during the MIS 9 interglacial

346 period of high sea level between 290 and $340 \mathrm{ka}$ (Figure 6). The Waelbroeck et al. (2002) sea-

347 level curve shows an abrupt rise in sea level at ca. $340 \mathrm{ka}$, whereas our data suggest sand

348 delivery to the fan was terminated at this time, and a thick mud and marl-rich unit was deposited

349 until about $290 \mathrm{ka}$. The GDEC-4 oxygen-isotope curve suggests that fans deposited between the 
900 SB and the 900 FS represent the MIS 8 glacial period of low sea level between ca. 240 and

$351290 \mathrm{ka}$ (Figures 6 and 9). The GDEC-4 oxygen-isotope curve suggests that fine-grained

352 sediment in the interval between the $900 \mathrm{FS}$ and the $1000 \mathrm{SB}$, including marls 4, 5, 6 and 7 were

353 deposited during the MIS 7 interglacial period of high sea level between ca. 190 and $240 \mathrm{ka}$

354 (Figures 6 and 9).

355 Isopachs of the overlying 1000 SB to 1000 FS interval show a thickness trend that

356 suggests deposition of one large fan was deflected to the south by the toe of slope of the Pianosa

357 Ridge (Figure 11). However, more detailed mapping and breaking out an internal surface shows

358 that there are two distinct fans, the oldest fed by the North Golo Canyon and the youngest fed by

359 the South Golo (Figure 11). OSL ages from sands in this interval in GDEC-8 are as old as ca.

$360127 \pm 18.3 \mathrm{ka}$ which are consistent with deposition near the end of the MIS 6 glacial period of

361 low sea level.

362 The interval between the top of the $1100 \mathrm{SB}$ and the $1000 \mathrm{FS}$ is penetrated by the GDEC-

363 4, GDEC-6 and GDEC-8 cores, is mud-rich, and is characterized by the occurrence of one or two

364 thick $(>1 \mathrm{~m})$ marls (Figure 5). There are no OSL or ${ }^{14} \mathrm{C}$ dates from this unit, but the GDEC-4

365 oxygen-isotope curve suggests deposition between ca. 135 and $87 \mathrm{ka}$, corresponding to the MIS

3665 interglacial period: global sea level was at or slightly higher than present day during MIS 5.5,

367 and oscillated between -20 and -60 m during MIS 5.3 to 5.1 (Siddall et al., 2003).

368 The interval between the $1100 \mathrm{SB}$ and $1100 \mathrm{FS}$ represents the period ca. $65.6 \mathrm{ka}$ (based

369 on OSL ages) and ca. $15 \mathrm{ka}$ (based on ${ }^{14} \mathrm{C}$ ages), which corresponds to MIS 4 and 2 . This unit

370 can be divided between two distinct fans, which are separated by the $1300 \mathrm{SB}$. The older fan is

371 penetrated by the GDEC 8 core, yielded OSL ages of ca. 65.6 to $62.0 \mathrm{ka}$, and represents the MIS

3724 glacial period of low sea level. The younger fan is penetrated by the GDEC 6 core, yielded 
373 OSL ages and ${ }^{14} \mathrm{C}$ ages between ca. $31.7 \mathrm{ka}$ and $16.7 \mathrm{ka}$, and represents the MIS 2 last glacial 374 maximum period of low sea level (Figure 5)

375 The $1100 \mathrm{FS}$ is the shallowest zone that was mapped. OSL and ${ }^{14} \mathrm{C}$ dates show it to be

376 between $15 \mathrm{ka}$ and $10 \mathrm{ka}$. A muddy or marly layer occurs throughout the basin at the seafloor,

377 although there appears to be some preserved Holocene sediment that was deposited ca. 400 to $378 \quad 800$ years ago based on ${ }^{14} \mathrm{C}$ dates (Figure 5).

\section{DEPOSITIONAL ENVIRONMENTS}

The high-resolution bathymetric data acquired in this study provides a clear indication of

382 the depositional environments present today and in the recent past (Figure 2). When combined

383 with core and high-resolution seismic data, it was used to reconstruct how these environments

384 changed through time.

\section{Delta Lobes and Fluvial Channels on the Shelf}

The present-day Golo Delta is a wave-dominated delta with a pebbly to sandy topset and

388 shoreline, and distributary channels that are 30 to $75 \mathrm{~m}$ wide. High-resolution bathymetry and

389 seismic data show plan-view arcuate features with seaward-dipping internal reflectors at $-50 \mathrm{~m}$

390 and $-80 \mathrm{~m}$ below current sea level (Figures 4 and 12). A similar prominent feature with seaward-

391 dipping reflectors is found at the modern shelf-slope break at $-120 \mathrm{~m}$ below sea level (Figures 4

392 and 12). Cores from GDEC-1 and GDEC-3 demonstrate that sediment from the sea floor down to

$39350 \mathrm{mbsf}$ through these features is composed of sand and gravel (Figure 5). As a result, we

394 interpret these them to be the seaward-dipping clinothems of older deltas abandoned on the now-

395 flooded shelf. Bathymetric and seismic data further reveal that these older deltas are arranged in 
396 a back-stepping aggradational-retrogradational pattern, with the delta at $-120 \mathrm{~m}$ being the oldest,

397 and the delta at -50 being the youngest (Figure 4). Using geochronological data, we interpret the

$398-120$ clinothem to have formed ca. $20 \mathrm{ka}$ and represent the MIS2 Last Glacial Maximum (LGM)

399 deltaic shoreline, the $-80 \mathrm{~m}$ clinothem to have formed ca. $14 \mathrm{ka}$ and represent progradation after

400 the onset of the Older Dryas cold period, and the $-50 \mathrm{~m}$ clinothem to have formed ca. $12 \mathrm{ka}$ with

401 progradation initiated during the Younger Dryas cold period and continuing into the Holocene

402 (Figure 12).

Seismic data from the shelf also reveal three types of east-west-trending elongate units in

404 the shallow part of the section, which cross-cut and truncate older strata and are filled with high-

405 amplitude discontinuous facies that are distinctive from the seaward-dipping deltaic clinothems

406 (Figure 4). An example of the first type is a $70 \mathrm{~m}$-wide lenticular deposit just a few meters deep,

407 which is similar in size to the distributary channels of the modern Golo River, and interpreted to

408 represent a distributary channel of the Golo River when it was extended across the shelf to the -

$40950 \mathrm{~m}$ shoreline. The second type of elongate unit occurs buried at the head of both the North and

410 South Golo Canyons (Figure 13). These features can be mapped on multiple seismic lines, are up

411 to $2.5 \mathrm{~km}$ wide and 10 's of meters in thickness, extend across the shelf from the western edge of

412 our seismic data (Figure 13), and are interpreted to represent cross-shelf paleovalleys (sensu

413 Blum et al., 2013) that were cut by the Golo River during periods of low sea level. The downdip

414 extension of the most recent paleovalley was penetrated by the GDEC 3 core between 10 and 18

415 mbsf, which sampled mostly fine to coarse sand and a small amount of conglomerate (Figures 4,

4165 and 13a): ${ }^{14} \mathrm{C}$ dates indicate this paleovalley was filled during the last $15 \mathrm{ka}$.

417 The third type of east-west trending erosional unit is also large but cuts deeper than

418 paleovalleys and pinches-out rapidly landward. Two examples are seen on seismic line Sigolo- 
067 directly at the head of the South Golo Canyon (deepest features on Figure 13). The youngest

420 unit, which cuts into the previous one, reaches $70 \mathrm{~m}$ in depth and a kilometer in width. We

421 interpret these features as the updip extension of the South Golo Canyon as it underwent multiple

422 phases of cut and fill. Unfortunately, we have no core data to constrain the age or lithology of the

423 fill. However, the seismic horizon associated with one of these cuts (1100 SB) can be correlated

424 to the GDEC-1 core where OSL dating suggests that it is younger than 89 ka (Figure 5).

425 All of the above features, from the distributary channel-fill deposit to the paleovalley-

426 and canyon-fills suggest that the paleo-Golo River discharged directly into the heads of North

427 and South Golo canyons when sea level was low (Figure 14). In addition, Golo River sediment

428 appears to have been delivered to mouth bars that impinged on the head or margins of both

429 canyons until sea level was high enough to prevent the connection (Figures 10 and 14). This

430 relationship is especially clear for the $-120 \mathrm{~m}$ deltaic clinothem, which represents the last glacial

431 maximum period of minimum sea level, whereas the regressive deltaic clinothem at $-80 \mathrm{~m}$,

432 which formed ca. $14 \mathrm{ka}$, is interpreted to be the last one to closely approach the head of the South

433 Golo Canyon (Figure, 4, 12, and 14). The 1100 SB represents the initiation of the connection

434 between a paleo-Golo River and the North and South Golo paleo-canyons and ends with a

435 disconnection that occurred sometime before deposition of the younger Dryas clinothem at ca. 12

436 ka. Disconnecting the Golo sand source from the canyon at ca. 14 ka is consistent with the

437 youngest sand seen in our data from the basin floor as well (Figure 5).

\section{Slope Canyons and Gullies}

440 The Golo margin in the study area is penetrated by two large submarine canyons (the

441 North and South Golo), two smaller canyons near the north edge of the study area (the Biguglia 
442 and St. Domiano) and two straight, slope gullies, the Fium Alto and Pineto (Figure 12). The

443 North and South Golo canyons feed extensive submarine fans and appear to be the primary

444 conduits for sediment into the basin in our study area.

445 The South Golo Canyon reaches a maximum depth of $150 \mathrm{~m}$. It penetrates about $1.5 \mathrm{~km}$

446 headwards across the shelf from the shelf-slope break and extends $7 \mathrm{~km}$ down the slope. The

447 canyon begins to develop levees and makes the transition into a levee-confined channel at the

448 base of slope, in about $450 \mathrm{~m}$ water depth (Figures 12, 13, and 15). The canyon ranges in width

449 from $600 \mathrm{~m}$ at its head to a maximum of $3300 \mathrm{~m}$. In the upper reaches, canyon edges are smooth

450 and the base of the canyon is flat. Seismic data indicate lateral migration of the South Golo

451 Canyon to the north through time. Further down the canyon prominent terraces develop (Figure

452 13). We have no core data from any of the canyons or gullies, but the moderate amplitude, high-

453 continuity seismic facies of the terraces suggest that they are composed of a heterolithic mix of

454 sand and mud. Similar lithologies have been reported by Jobe et al. (2015) from cores in

455 submarine canyons terraces off of the Niger Delta. The base of the canyon is filled with a low-

456 continuity, high- amplitude seismic facies that we interpret as coarse-grained sediments that

457 could be as coarse as the gravel-sized sediments seen in the GDEC-1 core from the Golo shelf.

458 The filling history of the canyon is complex with evidence of incision, lateral migration, and

459 aggradation of the fine-grained slope deposits outside of the canyon and coarse-grained deposits

460 in the deepest part of the canyon (Figure 13). Seismic data show that there are older, now

461 sediment-filled canyons below the most recent canyon. Cross-cutting relationships between the

462 canyon margins and dated seismic horizons suggest that the South Golo Canyon began to form at 463 least $450 \mathrm{ka}$ ago, before the time of the $700 \mathrm{SB}$ (Figure 13) 
465 North Golo Fan (Figure 12). The North Golo Canyon penetrates headward about $1000 \mathrm{~m}$ into the 466 shelf. It ranges in width from 1100 to $1700 \mathrm{~m}$ and is up to $200 \mathrm{~m}$ deep. Seismic data show that at 467 least two older, sediment-filled canyons exist beneath the Pineto Gully which are on the scale of 468 the present-day North Golo Canyon.

469 In contrast to the North and South Golo canyons, which have sinuous planform 470 geometries, the smaller Pineto and Fium Alto gullies are narrow and straight (Figure 12). Cross471 cutting relationships observable in seismic data suggests they are young features formed by 472 collapse at the shelf-slope break without a long-lasting connection to a river-mouth or shoreline 473 feeder system on the shelf. The two gullies have preserved only a thin veneer of deposits since 474 they formed. The Fium Alto Gully ranges in width from 660 to $200 \mathrm{~m}$ and has a maximum depth 475 of $40 \mathrm{~m}$. The lower reaches of the Fium Alto Gully, while largely erosional, also have low, 476 incipient levees. There is a small fan at the base of the slope at the terminal end of this gully that 477 is about $1.6 \mathrm{~km}$ wide and up to $24 \mathrm{~m}$ thick. The Pineto Gully ranges in width from 540 to $240 \mathrm{~m}$ 478 wide and up to $40 \mathrm{~m}$ deep. The lower reaches develop low levees and there is evidence from 479 seismic data of less erosion at the base of the gully and more aggradation of high-amplitude 480 discontinuous seismic facies that we interpret as coarse-grained deposits. One seismic line at the 481 terminus of the Pineto Gully shows a small (1.2 km wide), thin (about $20 \mathrm{~m}$ thick) fan that 482 developed downdip of the gully. Cross-cutting relationships with dated seismic horizons suggest 483 that the Pineto Gully has only exited since MIS-2. 


\section{Levee-Confined Channels}

Both the North and South Golo fan channels are characterized by levee-confined reaches

487 (Figure 15). In the levee-confined reach of the South Golo, the channel is 400 to $600 \mathrm{~m}$ wide and 488 has levees that extend $\sim 900-1500 \mathrm{~m}$ on either side of the channel to where they pinch out 489 forming wedge-shaped deposits. As observed by Skene et al. (2002) in their data of levee 490 heights, the Golo levees thicknesses decrease down channel toward the channel-lobe transition

491 (Figure 15). The South Golo channel extends $22 \mathrm{~km}$ from the South Golo Canyon to the channel492 lobe transition (Figure 15). The GDEC-8 core shows that the levee at that location is primarily 493 composed of mud with a few thin beds of fine to very fine sand and silt located near its base

494 (Figure 8). The composition of levee deposits in the more distal reaches of the South Golo 495 channel is not known.

The North Golo channel extends $10.3 \mathrm{~km}$ from the North Golo Canyon to the North Golo 497 Fan. A recent avulsion associated with the development of a large lobe complex at the toe of 498 slope explains the shorter length of the North Golo channel relative to its southern counterpart. In 499 a region down-dip of the latest lobe complex toward mid-basin, bathymetry indicates that the 500 North Golo channel extended farther out into the basin. In the levee-confined area, the North 501 Golo channel ranges from 800-1000 m wide and is situated between $50 \mathrm{~m}$-high levees that 502 extend about a kilometer on either side of the channel. A 250 m-wide, slightly sinuous thalweg is 503 bordered by occasional terraces or internal levees, and represents the most recent path for 504 sediment-gravity flows before abandonment by avulsion. 


\section{Lobes and Channel-Lobe Transitions}

As levees become lower and the relief of channels decreases basinward, large lobate

507 bodies develop, eventually occupying most of the lower-gradient regions. Their expression on

508 seismic data is characterized by a conformable, locally erosional base and a mounded top with

509 continuous to semi-continuous, high-amplitude reflections (Figure 16). Downlapping geometries

510 are observed along their basal margins (Figure 16). Following the nomenclature used by Prélat et

511 al. (2010) we interpret these features as lobe complexes, as they represent the highest order of

512 lobate bodies that can be linked to an individual branch of a levee-confined channel. In this

513 model, avulsion along the levee-confined portion of the channel is necessary to initiate a new

514 lobe complex. Within lobe complexes, we then define a hierarchal set of nested components to

515 be lobes, lobe elements, bed sets and beds, with the basic principle that one or more components

516 stack to form the next larger component of the hierarchy (Prélat et al., 2009).

517 On its most recent southerly path, the South Golo channel transitions into a lobe complex

$51812 \mathrm{~km}$ long and up to $10 \mathrm{~km}$ wide with a maximum thickness of $65 \mathrm{~m}$. The GDEC-6 core

519 penetrates $\sim 50 \mathrm{~m}$ of deposits dominated by fine sand ( $85 \%)$, but with grain sizes that range from

520 very fine sand to gravel (Figures 5 and 7). The mud in this core is typically expressed as meter-

521 thick beds that are interbedded with thicker beds of well-sorted sand (Figures 5, 7, and 16). The

522 lobe complex thins to 10-15 m towards its margins where it merges with a constant thickness

523 layer of low amplitude seismic facies that is very continuous throughout the basin. This unit,

524 where penetrated by cores GDEC-4 and GDEC-8 (Figures 6 and 8 respectively), is composed of

525 mud with silt laminations. The transition from the sandy lobe complex to the constant thickness

526 mud-rich unit can be gradational with high-amplitude reflectors from the lobe complex gradually 
527 decreasing in amplitude, or it can be abrupt with sharp internal onlaps onto the lower amplitude 528 continuous reflectors of the regional unit (Figure 17).

529 Internal seismic geometries within the lobe complex show that it is composed of the

530 nested smaller bodies we interpret as lobes and lobe elements following the Prélat et al. (2010)

531 terminology (Figures 16 and 17). Within the lobe complex, individual lobes are bounded at the

532 base by bidirectional onlap and downlap, and at the GDEC-6 location they correspond to the

533 blocky sand packages with the thicker mud-rich units defining their upper and lower boundaries.

534 Six lobes have been identified within the South Golo lobe complex. They range in maximum

535 thickness between 20-30 m with dip-elongated shapes averaging $6 \mathrm{~km}$ long and $3 \mathrm{~km}$ wide. They

536 stack compensationally and show evidence of progradation, retrogradation, and lateral offset.

537 Individual lobes are connected to individual distributary channels that branch from the main

538 levee-confined channel upstream (Figure 16). None of these distributary channels or their lateral

539 deposits have been cored so the nature of their deposits are unknown, although the high

540 amplitude nature of their reflectors suggests a heterolithic composition overall.

541 Lobe elements are the smallest units that can be mapped with our seismic data, and

542 consist of packages of reflectors that thin toward the margins and thicken towards the center of

543 the lobe (Figure 16). We observe progressive upflow and lateral shifts in the locations of the

544 thickest part of these lobe elements. It is possible to distinguish 4 to 5 lobe elements within a

545 typical lobe, each with a maximum thickness of 5-15 m. Each lobe element has an elongated

546 shape with an average length of $8 \mathrm{~km}$ and an average width of $3 \mathrm{~km}$. A central erosive feeder

547 channel is linked to unconfined deposits, a mouth bar, where the maximum thickness is

548 observed. When traversed by dip-oriented seismic lines, successive lobes elements appear as

549 shingled, retreating bodies with flat tops as opposed to "backsets" where the top of the sediment 
550 body dips up-flow (Figure 16). Where penetrated in the GDEC-6 core, they are composed of 551 sand with grain size ranging from very fine to coarse sand, even at their margins (Figure 16). In

552 cross-section, lobe elements taper distally to a down-lap limit (present all along the mouth-bar

553 periphery) where they join a tabular section where the lobe-element fringe transitions from

554 interbedded mud and sand to bioturbated mud. The interpreted zero sand line occurs within the

555 lobe element fringe a few $100 \mathrm{~m}$ away from the down-lap limit. The retrogradational stacking of

556 lobe elements juxtaposes sand on sand between successive mouth-bars (Figure 16). The

557 retrograding mouth bars also end up overlaying preceding feeder channels building sandy

558 wedges that look like levees. At the scale of lobes, compensational stacking results in the inter-

559 fingering of sandy mouth-bars with muddy fringes from other lobes. The general distribution of

560 mud and sand in a lobe complex is illustrated in Figure 17.

The same geometries of lobes and lobe complexes can be observed within the lobe

562 complex attached to the North Golo channel as well as older lobe complexes throughout the

563 basin (Figure 16). The youngest lobe complex of the North Golo Fan developed at the location of

564 a recent avulsion from a well-developed levee-confined channel in the toe-of-slope area. Its base

565 is erosional at the location of the avulsion, becoming conformable downdip while its top is

566 mounded. At the avulsion location, the lobe complex develops on top of the abandoned channel-

567 levee system and it is difficult to distinguish the channel-fill deposits from the base of lobe

568 complex as the seismic facies are very similar (high amplitude, semi-continuous). Downdip of

569 the avulsion site the contact between the lobe and the abandoned levees is very sharp with clear

570 onlaps and downlaps of the lobe reflections onto the abandoned levee top (Figure 16). This lobe

571 complex reaches $6 \mathrm{~km}$ in length and $4 \mathrm{~km}$ in width and a maximum thickness of $30 \mathrm{~m}$. It is built

572 with two or more lobes with clear internal backstepping geometries. A transition to regionally 
573 continuous and parallel reflections occurs on the margins of the avulsion lobe complex in a

574 manner similar to the South Golo lobe complex. This layer thins to $7 \mathrm{~m}$ on the fringe of the lobe 575 complex (Figure 16b).

576 Well-developed lobe complexes are also expressed on the seafloor and on seismic lines at 577 the mouth of abandoned portions of the North and South Golo channels (Figure 17). They vary 578 in size, shape and thickness compared to the lobe complex attached to the latest South Golo 579 channel. These lobe complexes are between 5 and $10 \mathrm{~km}$ long, 4 and $8 \mathrm{~km}$ and 35 to $70 \mathrm{~m}$ thick.

580 The size and shape of the lobe complexes vary with the number of their constituent lobes and 581 their stacking patterns, which are all linked to avulsion processes. The governing factors for 582 location and frequency of avulsions will be discussed in a later section in parallel with the timing 583 of sedimentation in the basin and in relation to internal versus external forcings.

$584 \quad$ By contrast, lobe complexes attached to gullies are much smaller and are generally 585 composed of only one or two lobes. The Fium Alto Gully, in the southern part of the study area, 586 feeds a single lobe $5 \mathrm{~km}$ long and $3 \mathrm{~km}$ wide with a maximum thickness of $20 \mathrm{~m}$. The Fium Alto 587 lobe was deposited at the toe-of-slope against the South Golo lobe, which prevented further 588 elongation. The Pineto Gully lobe, located between the North and South Golo canyons, reaches 8 $589 \mathrm{~km}$ in length and $2 \mathrm{~km}$ in width. This is a very elongate lobe confined between the two leveed 590 channel systems. Over the Golo slope the gully lobes show larger ratios of lobe-element 591 thickness to channel depth than the lobe elements developed further downdip in the channel592 levee/lobe complexes. This characteristic has been linked by Hamilton et al. (2017) to the steeper 593 gradients on which they develop based on physical experiments validated by observations from 594 the Golo seismic data. 


\section{DEPOSITIONAL RATES}

Depositional rates and sand-to-mud ratios for each of the sand-rich fans and the

598 associated mud-rich intervals we mapped are shown in Table 2. Sediment volumes have been

599 calculated inside an area of the basin where coverage by 2D seismic lines is sufficient to

600 accurately depict the boundaries between sand bodies. This area most likely does not cover the

601 entire reach of the fans and thus may underestimate the volume of sand and mud accumulated in

602 the basin as a whole. Age constraints for deposits less than ca. $100 \mathrm{ka}$ in age are based on OSL

603 and ${ }^{14} \mathrm{C}$ ages, and correlations between $\delta^{18} \mathrm{O}$ values in GDEC4 and global curves, whereas units

604 older than ca. 100 ka relied solely on $\delta^{18} \mathrm{O}$ data. Mud-rich intervals, which record deposition

605 during times of high relative sea level, are characterized by sedimentation rates of 0.07 to 0.17

$606 \mathrm{~m} / \mathrm{ka}$, whereas periods of active sand-rich fan deposition occurred when sea level was low, and

607 had higher deposition rates of 0.35 to $0.59 \mathrm{~m} / \mathrm{ka}$. Deposition rates when sea level is low are

608 therefore 3-8 times greater than during periods of higher sea level, but the difference was not as

609 large as we had anticipated because muds dominate the overall sediment load, and significant

610 volumes of fine-grained sediment are dispersed across the basin, even in times of high sea level.

611 It is important to keep in mind that these rates are averaged over the entire basin and that

612 depositional rates at locations like an active channel-lobe transition must be much higher. The

613 most profound difference was the lack of sand deposited in the basin once sea level rose above -

$61480 \mathrm{~m}$, relative to present, and Golo River sand supply became disconnected from the North and

615 South Golo canyons. Even during the Younger Dryas period of deltaic construction on the shelf,

616 the Golo River mouth did not come close enough to the canyon heads to allow sand to be

617 transferred to deep water. 
DISCUSSION

\section{Distribution of Sand Versus Mud Through Time}

621 Consistent with existing sequence-stratigraphic models (e.g., Vail, 1987; Posamentier and

622 Vail, 1988), deposition of sand in the Golo system reflects climate-forced sea-level controls, with

623 sand-rich fans deposited when sea level was below about $-80 \mathrm{~m}$, the Golo River and delta had

624 extended across the shelf, and a there was a direct connection between the Golo River mouth and

625 the upper reaches of submarine canyons and gullies. Deposition of significant volumes of mud

626 and carbonate-rich sediments also occurred in the basin when sea level was rising and high, as

627 previously shown at the GDEC-4 site (Toucanne et al., 2015). This observation is consistent

628 with Sweet and Blum (2016) whose data showed that systems with narrow shelves should leak

629 large quantities of mud into the basin even in times of relatively high sea level. It is likely that

630 with better age control we would see rates of sedimentation decreasing over the last 14 ka when

631 post-glacial sea-level rise was rapid (Deschamps et al., 2012), since the older (lower) part of the

632 post-glacial succession is marked by mud deposition in the basin, and the youngest sediments at

633 the seafloor are marls. Sømme et al. (2011) and Forzoni et al. (2015) argue that during periods

634 of high sea level coarse-grained sediments are interred in onshore terraces and in the

635 aggradational coastal plain. Our seismic data also suggest that coarse-grained sediments build

636 delta lobes on the shelf when sea level is above $-50 \mathrm{~m}$, which are captured in the fill of cross-

637 shelf paleovalley systems (Figures 12 and 13). Unfortunately, there are no published seismic data

638 across the modern Golo Delta to determine the volume of sediment captured there. The modern

639 delta is a very small feature and we imagine that the majority of coarse-grained sediments are

640 captured in the alluvial plain during highstands. However, our cores and published data suggest 
641 the Tyrrhenian Current sweeps the modern shelf of fine-grained sediment and transports it to the 642 north.

643 During glacial periods of low sea level, when the coastal plain part of the Golo River

644 incised through previous deposits and the channel extended across the shelf, sediment was

645 cannibalized from older fluvial terraces (Sømme et al., 2011; Forzoni et al., 2015) and shelf

646 deposits. Our mapping shows evidence of cross-shelf paleovalleys that connected the Golo River

647 directly to the North and South Golo canyons (Figure 13). During these periods mud was

648 partitioned in the basin into slope, mud-rich levees and the muddy fringes of the sand-rich fans.

649 The presence of multiple, stacked shelf edge deltas (Figure 4) demonstrates that

650 subsidence of the Golo shelf has created enough accommodation to preserve about $70 \mathrm{~m}$ of

651 coarse-grained sediment over the last $300 \mathrm{ka}$.

652

\section{Comparison to Other Quaternary Fans}

The North and South Golo fans have all of the depositional elements of other Quaternary

655 Fans like the Congo (Babonneau et al., 2002), Rhone (Droz and Bellaiche, 1985), Mississippi

656 (Weimer, 1989), Hueneme (Piper et al., 1999) and Danube (Popescu et al., 2001). They are fed

657 by submarine canyons, and turbidity currents then transit through a reach of levee-confined

658 channels to a down-dip, sand-rich fan. The sand-rich part of the fan has a lateral facies

659 relationship with a mud-rich fan fringe.

660 Smaller fans in tectonically active margins, like the Golo and Hueneme Fan of California

661 (Piper et al., 1999), display important differences from large passive-margins fans like the

662 Danube and Congo that go beyond the obvious differences in scale (10's versus100's to1000's of

$663 \mathrm{~km}$ in extent and 10's versus 100's of $\mathrm{m}$ in thickness). Large passive-margin systems are 
664 relatively unconfined on a low-gradient sea floor whereas the Golo is constrained by a sea floor

665 structural high (the Pianosa Ridge). The proportion of muddy leveed-channels versus sand-rich

666 fans vary greatly between fans like the Golo and their large passive-margin counterparts.

667 Moreover, fan lobes on the Golo display a back-stepping pattern of development that may be 668 characteristic of supercritical fans (Hamilton et al., 2017), and as a result the reach of levee669 confined channels is short relative to overall fan length. In the case of the active channel of the

670 Congo Fan the leveed channel extends for $1100 \mathrm{~km}$ feeding a terminal lobe that is about $35 \mathrm{~km}$

671 long (Babonneau et al., 2002). Data on the recent channels of the Amazon Fan show similar

672 trends where the Brown Channel extends $580 \mathrm{~km}$ and feeds a lobe $45 \mathrm{~km}$ long (Jegou et al.,

673 2008). The resulting deposit of the entire fan consists largely of mud-rich levee deposits that are

674 interleaved with sand-rich terminal lobes. In the case of the Golo and other fans in tectonically

675 active margins, the levee-confined reaches are no more than 1.3 to 2.4 times the length of the

676 lobe. The overall result is a deposit that is more dominated by lobes than levees, though both are

677 present. Nonetheless the Golo differs from published models of sand-rich fans (e.g. Reading and

678 Richards, 1994) in that there are significant reaches of mud-rich, levee-confined channels that

679 separate the sand-rich lobes from the submarine canyon.

680 Our mapping and chronological framework shows that deep-water sediments of the

681 Corsica Basin can be divided into $100 \mathrm{ka}$ depositional sequences. The sequences can be divided 682 into shorter duration systems tracts. Lowstand systems tracts bounded at the base by regional 683 downlap (within sand-rich fan deposits), onlap and erosion, which we interpret to represent 684 classical sequence boundaries that record sea-level fall, extension of the Golo River across the 685 shelf, and initiation of sand delivery to the basin floor. The transgressive and highstand systems 686 tracts that compose the upper part of the sequence are composed of up to $10 \mathrm{~m}$ thick packages of 
mud and marl, which are interpreted to represent sea-level rise and flooding of the shelf,

688 backstepping of the Golo River mouth, and cessation of sand delivery to the basin. Our youngest

689 depositional sequence represents the last 100 ka glacial-interglacial cycle (MIS 5-1), but can be

690 further subdivided due to higher-resolution chronological control: for this sequence we

691 differentiate distinct cross-shelf extension of the Golo River to the shelf margin, and sand-rich

692 fan deposition on the basin floor, during the MIS 4 and 2 periods of low sea level, with

693 backstepping of the Golo River and cessation of sand delivery during the intervening MIS 3

694 period of sea-level rise to mid shelf positions. Sweet and Blum (2016) suggest this higher-

695 frequency change should be characteristic of small systems with inherently narrow shelves,

696 which would contrast with large systems with wide shelves, where sand-rich deposition may be

697 restricted to the MIS 2 last-glacial maximum sea-level lowstand.

698 Last, within and between individual depositional sequences we observed shifts of

699 depocenters where sand was routed down either the North or South Golo Canyon, and coeval

700 muddy deposits blanketed the rest of the basin. We interpret these changes to have been driven

701 by autogenic avulsion processes acting in the lower reaches of the Golo River, and/or on the

702 Golo Delta, which caused the Golo River to connect with, and the sand load to be routed down,

703 by turns, the North or South Golo canyons. Although of a different scale, Blum et al. (2018)

704 interpreted similar signals of autogenic avulsion of the Ganges-Brahmaputra Rivers within the 705 deep-sea Bengal Fan.

706

\section{CONCLUSIONS}

708 1) Connections for sand movement between fluvial/deltaic systems and submarine canyons 709 occur when shorelines migrate basinward, paleo-valleys cut the shelf during periods of 
sea-level fall, and river mouths or deltaic lobes connect directly with the heads of submarine canyons. Even given the relatively narrow shelf of the eastern Corsica margin, sand transport to the fans is restricted to relatively small percentages of time when sea level was $-80 \mathrm{~m}$ or more below its current level and the Golo River and/or delta had a be advected up to several kilometers across the shelf and, as a result, mud deposition occurs over a much wider range of sea level conditions and represents a significantly larger percentage of time.

2) Canyon evolution on the Golo shelf margin and slope includes some incision, but also aggradation of entire margin and of canyon-fill deposits. Canyons migrated laterally and are from time to time abandoned and filled. The main feeder canyons of the Golo system are long-lived having begun form at least $450 \mathrm{ka}$ ago.

3) The reach of levee-confined channels is short compared to large passive-margin systems like the Danube, Amazon and Congo. Levee to lobe length is in the ratio of 1:1 or 1.5:1 on the Golo compared to 10's: 1 in the case of the Congo, Danube and Amazon. This is significant because large qualities of mud are trapped in the levees of large fans, whereas mud in the Golo system occurs as drapes and as extensive muddy fringes to the sandy lobes. This is distribution of mud is probably characteristic of most short, steep fans like the Golo.

4) Deposition rates in the deep basin vary by a factor of up eight times between periods of low versus rising or high sea level. Sand deposition appears to be restricted to periods of low sea level ( $-80 \mathrm{~m}$ below present), when river mouths are proximal (within $\sim 2 \mathrm{~km}$ ) to canyon heads. 
5) Response of the Golo River to allogenic, climate-forced sea-level change plays the overarching role in determining rates and grain size of sediment supplied to the basin. However, autogenic factors such as avulsion of the Golo River and its deltaic system laterally across the shelf, and avulsion and lobe switching on the submarine fans themselves, control where deposition of sand-sized sediment is localized within depositional sequences.

\section{ACKNOWLEDGEMENTS}

The late Bruno Savoye first proposed the idea of a detailed seismic and coring program

741 on the Golo system. He was instrumental in acquiring the 2D seismic data, but tragically died

742 soon afterward. This study would have been impossible without his work. Gilles Lericolais

743 played an important role in coordinating the study from Ifremer after Bruno's death, and in

744 planning the coring program. Funding came from a consortium of the Institut français de

745 recherche pour l'exploitation de la mer (Ifremer), Total E\&P Recherche Developpment,

746 ExxonMobil Upstream Research Company, and Fugro N.V. We acknowledge ExxonMobil

747 Research Company for supporting our work and giving us permission to publish. The captain

748 and crew of the RV Le Suroit showed great skill in acquiring the 2D seismic survey and high-

749 resolution bathymetry used in this study. The captain and crew of the drillship Bavenit did an

750 outstanding job of cutting core in a very challenging mix of lithologies. Over the years a number

751 of geoscientists at ExxonMobil, Ifremer, and Total have contributed to the Golo project. We

752 acknowledge Vitor Abreu, Martine Bez, Gérome Calves, Simon Charrier, Bernard Dennielou,

753 Tina Drexler, Laurence Droz, Francis Ezeh, Gilbert Floch, Isabelle Jégou, Stephan Jorry, Katie

754 Love, Bill Heins, Caroline Labaune, Elodie Marches, Angélique Roubi, and Mickael Rovere for 755 their contributions to this project. Our ExxonMobil colleagues Paul Dunn, Howard Feldman, 
756 David Hoyal, and Mauricio Perillo read drafts of this paper and challenged us to clarify our ideas

757 and our writing. GSA Bulletin Science Editor Dr. Rob Strachan, Associate Editor Dr. Rajat

758 Mazumder, and reviewer Dr. Octavian Catuneanu provided important suggestions to help us

759 improve the final quality of our paper. We extend a special thanks to GSA reviewer Dr. Richard

760 N. Hiscott who very carefully reviewed the manuscript twice and caught many errors and

761 inconstancies in the text.

762

\section{REFERENCES}

764 Aitken, M.J., 1998, An introduction to optical dating: The dating of Quaternary sediments by the 765 use of photon-stimulated luminescence: Oxford, University Press, 267 p.

766 Astraldi, M. and Gasparini, G.P., 1992, The seasonal characteristics of the circulation in the 767 north Mediterranean Basin and their relationship with the atmospheric-climatic conditions: Journal of Geophysical Research, v. 97, p. $9531-9540$.

769 Babonneau, N., Savoye, B., Cremer, M., and Klein, B., 2002, Morphology and architecture of 770 the present canyon and channel system of the Zaire deep-sea fan: Marine and Petroleum $771 \quad$ Geology, v. 19, p. 445 - 467.

772 Bellaiche, G., Droz, L., Gaullier, V., and Pautot, G., 1994, Small submarine fans on the eastern margin of Corsica: sedimentary significance and tectonic implications: Marine Geology,

775 Blum, M. D., Martin, J., Milliken, K., and Garvin, M., 2013, Paleovalley systems: Insights from 776 Quaternary analogs and experiments: Earth-Science Reviews, v. 116, p. $128-169$. 
Blum, M. D., Rogers, K. G., Gleason, J. D., and Najman, Y., 2018, Fingerprints of Climate Change in the Detrital-Zircon U-Pb Record of the Deep-Sea Bengal Fan? : American Geophysical Union, Fall Meeting 2018, abstract \#T23C-0386.

Calves, G., Toucanne, S., Jouet, G., Charrier, S., Thereau, E., Etoubleau, J., Marsset, T., Droz, L., Bez, M., Abreu, V., Jory, S., Mulder T., and Lericolais, G., 2013, Inferring the denudation variations from the sediment record; an example of the last glacial cycle record of the Golo Basin and watershed, East Corsica, western Mediterranean Sea: Basin Research, v. 25, p. 197 - 218.

Catuneanu, O., 2019, Model-independent sequence stratigraphy. Earth-Science Reviews, v. 188, p. 312-388.

Deptuck, M. E., Piper, D. J. W., Savoye, B., Gervais, A., 2008, Dimensions and architecture of late Pleistocene submarine lobes off the northern margin of East Corsica: Sedimentology, v. 55, p. $869-898$.

Deschamps, P., Durand, N., Bard, E., Hamelin, B., Camion, Thomas, A. L., Henderson, G. M., Okuno, J., and Yokoyama, Y., 2012, Ice-sheet collapse and sea-level rise at the Bolling warming 14,600 years ago: Nature, v. 483, p. 559 - 564, doi: 10.1038 /nature10902 .

Droz, L., and Bellaiche, G., 1985, Rhone deep-sea fan: Morphostructure and growth patterns: American Association of Petroleum Geologists, Bulletin, v. 69, p. 460 - 479.

Duplessy, J.C., 1978, Isotope studies: Climatic change, v. 3, p. 47-67.

Forzoni, A., Storms, J. E. A., Reimann, T., Moreau, J. and Jouet, G., 2015, Non-linear response of the Golo River system, Corsica, France to Late Quaternary climatic and sea level variations: Quaternary Science Reviews, v. 121, p. 11-27. 
Gervais, A., 2002, Analyse multi-échelle de la morphologie, de la géométrie et de l'architecture d'un système turbiditique sableux profond (System du Golo Marge est-Corse, Mer Méditerranée). Ph.D. Dissertation University of Bordeaux, 285 p.

802 Gervais, A., Savoye, B., Piper, D. J. W., Mulder, T., Cremer, M., and Pichevin, L., 2004, Present morphology and depositional architecture of a sandy confined submarine system: the Golo turbidite system (eastern margin of Corsica), in Lomas, S. A. and Joseph, P., eds., Confined Turbidite Systems: London, Geological Society [London] Special Publication, v. 22, p. $59-89$.

Gervais, A., Mulder, T., Savoye, B., and Gonthier, E., 2006, Sediment distribution and evolution of sedimentary processes in a small sandy turbidite system (Golo system, Mediterranean Sea): implications for various geometries based on core: Geo-Marine Letters, v. 26, p. 373-395.

Gabin, R., 1972, Resultats d'un etude sismique reflexion dans le canal do Corse, et de sondeur de vase dans le bassin Toscan : Marine Geology, v. 13, p. $267-286$.

Hamilton, P., Gaillot, G., Strom, K., Fedele, J., Hoyal, D., 2017, Linking hydraulic properties in supercritical submarine distributary channels to depositional-lobe geometry: Journal of

816 Hsu, K., 1973, The desiccated deep-basin for the Messinian events: In Drooger, C. W., ed., The Messinian Events in the Mediterranean: Amsterdam, North Holland Publishing Co., p. 60-67.

819 Jegou., I., Savoye, B., Pirmez, C., and Droz, L., 2008, Channel-mouth lobe complex of the recent 820 Amazon Fan: the missing piece: Marine Geology, v. 252, p. 62 -77. 
821 Jobe, Z.R., Sylvester, Z., Parker, A.O., Howes, N., Slowey, N., and Pirmez, C., 2015, Rapid adjustment of submarine channel architecture to changes in sediment supply: Journal of Sedimentary Research, v. 85, p. 729-753, doi: 10 .2110/jsr.2015.30.

824 Jolivet, L., Faccenna, C., Goffé, B., Mattei, M., Rossetti, F., Brunet, C., Storti, F., Funiciello, R., 825 Cadet, J. P., d'Agonstino, N., and Parra, T., 1998, Midcrustal shear zones in postorogenic

Jouet, G., 2018, GOLODRILL cruise, RV Bavenit, https://doi.org/10.17600/18000744

829 Lisiecki, L. E. and Raymo, L. E., 2005, A Plio-Pleistocene stack of 57 globally distributed 830 benthic $\delta 0^{18}$ records: Paleooceanography, v. 20, PA1003.

831 Mauffert, A., Contrucci, I., and Brunet, C., 1999, Structural evolution of the Northern Tyrrhenian Sea from new seismic data: Marine and Petroleum Geology, v. 16, p. $381-407$.

833 Maier, K. L., Fildani, A., McHargue, T. R., Paull, C. K., Graham, S. A., and Caress, D.W., 2012, Punctuated deep-water channel migration: high-resolution subsurface data from the Lucia Chica Channel system, offshore California, USA: Journal of Sedimentary Research, v.

837 Minto'o, C. M. A, Bassetti, M-A., Toucanne, S., and Jouet, G., 2016, Distribution of ostrocod

Miramontes, E., Cattaneo, A., Jouet, G., and Garzigalia, S., 2016a, Implications of sediment dynamics in mass transport along the Pianosa Ridge (Northern Tyrrhenian Sea): in G. Lamarche, ed. Submarine Mass Movements and their Consequences, Advances in 

Switzerland, p. 301-309.

846

Miramontes, E., Cattaneo, A., Jouet, G., Thereau, E., Thomas, Y., Rovere, M., Cauquil, E., Trincardi, F., 2016b, The Pianosa contourite depositional system (Northern Tyrrhenian Sea): drift morphology and Plio-Quaternary stratigraphy: Marine Geology, v. 378, p. 20 42.

Mitchum, R. M., 1985, Seismic stratigraphic expression of submarine fan, in, O. R. Berg and D. G. Woolverton, eds., Seismic Stratigraphy II: An integrated approach to hydrocarbon exploration: Tulsa, AAPG Memoir 39, p. 117 -136.

Mulder, T. and Maneaux, E., 1999, Flux et bilan sédimentaires. Impact d'apports fluviatile sur la construction des éventails sous-marin profond de la marge Est-Corse, Université Bordeaux I, Rapport interne, p. 20.

Murray, A. S. and Wintle, A. G., 2000, Luminescence dating of quartz using an improved single-aliquot regenerative-dose protocol: Radiation Measurements, v. 32, p. 57-73.

Murray, A. S. and Wintle, A. G., 2003, The single aliquot regenerative dose protocol: potential for improvements in reliability: Radiation Measurements, v. 37, p. 377-381.

Neal. J and Abreu, V., 2009, Sequence stratigraphy hierarchy and the accommodation succession method: Geology, v. 37, p. $779-782$.

Paull, C.K., Caress, D.W., Lundsten, E., Gwiazda, R., Anderson, K., McGann, M., Conrad, J., Edwards, B., and Summer, E.J., 2013, Anatomy of La Jolla Canyon system; offshore southern California: Marine Geology, v. 335, p. 16 -34.

Picot, M., Droz, L., Marsset, T., Dennielou, B., Bez, M., 2016, Controls on turbidite sedimentation: Insights from a quantitative approach of submarine channel and lobe 
architecture (Late Quaternary Congo Fan): Marine and Petroleum Geology, v. 72, p. 423446.

Piper, D.J.W., Hiscott, R. N., and Normark, R. W., 1999, Outcrop-scale acoustic facies and latest Quaternary development of Hueneme and Dume submarine fans, offshore California:

872 Pluquet, F., 2006. Evolution récente et sédimentation des plates-formes continentales de la Corse. Doctorat, Université de Corse, France.

874 Popescu, I., Lericolais, G., Panin, N., Wong, H.K., and Droz, L., 2001, Late Quaternary 875

Posamentier, H. W, and Vail, P. R., 1988, Eustatic controls on clastic deposition II - Sequence and Systems Tract Models, in, Wilgus, C. K., Hastings, B. S., Posamentier, H., Van Wagoner, J., Ross, C.A. and Kendall, C. G. St. C., eds., Sea Level Changes - An Integrated Approach: Tulsa, SEPM Special Publication 42, p. 125 - 154.

Prélat, A., Covault, J.A., Hodgson, D.M., Fildani, A., and Flint, S.S. 2010, Intrinsic controls on the range of volumes, morphologies, and dimensions of submarine lobes: Sedimentary Geology, v. 232, p. 66-76.

Prélat, A., Hodgson, D.M., Flint, S.S., 2009. Evolution, architecture and hierarchy of distributary deep-water deposits: a high-resolution outcrop investigation the Permian Karoo Basin, South Africa: Sedimentology v. 56, p. 2132-2154.

Reading, H.G. and Richards, M., 1994, Turbidite systems in deep-water basin margins classified by grain size and feeder system: American Association of Petroleum Geologists Bulletin v. 78, p. $792-822$. 
Reimer, P. J., Baillie, M. G. L., Bard, E., and Bayliss, A., 2009, Intcal09 and marine 09 radiocarbon age calibration curves, 0-50,000 years cal BP: Radiocarbon, v. 51, p.11111150.

Rittenour, T. M., Goble, R. J. and Blum, M. D., 2003, An Optical Age Chronology of Fluvial Deposits in the Northern Lower Mississippi Valley: Quaternary Science Reviews, v. 22, p. $1105-1110$.

Rittenour, T. M., Goble, R. J., and Blum, M. D., 2005, Development of an OSL chronology for late Pleistocene channel belts in the lower Mississippi valley: Quaternary Science Reviews, v. 24, p. 2539-2554.

Ryan, W. B., 2009, Decoding the Mediterranean salinity crisis: Sedimentology, v. 56, p. 95 136.

Savoye B., 2008, SIGOLO cruise, RV Le Suroît, https://doi.org/10.17600/8020110.

Shackelton, N.J., 2000, The 100,000-Year Ice-Age Cycle Identified and Found to Lag Temperature, Carbon Dioxide, and Orbital Eccentricity : Science, v. 289, p. 1897 - 1902.

Siani, G., Paterne, M., Michel, E., Sulpizio, R., Sbrana, A., Arnold, M., Haddad, G., 2001, Mediterranean Sea surface radiocarbon reservoir age changes since the last glacial maximum: Science, v. 294, p. 1917-1920.

Siddall, M., Rohling, E.J., Almogi-Labin, A., Hemleben, Ch., Meischner, D., Schmelzer, I., and Smeed, D.A., 2003, Sea-level fluctuations during the last glacial cycle: Nature, v. 423, p. $853-858$.

Skene, K. I., Piper, D. J. W., and Hill, P. S., 2002, Quantitative analysis of variations in depositional sequence thickness from submarine channel levees: Sedimentology, v. 49, p. $1411-1430$. 
912 SØmme T. O., D. J. W. Piper, M. E. Deptuk and W. Helland-Hansen, 2011, Linking onshore-

913 offshore sediment dispersal in the Golo source-to-sink system (Corsica, France) during

914 the late Quaternary: Journal of Sedimentary Research, v. 81, p. $118-137$.

915 Spratt, R. M. and Lisiecki, L. E., 2016, A Late Pleistocene sea level stack: Climate Past, v. 12, p.

916 1079-1092, https://doi.org/10.5194/cp-12-1079-2016, 2016

917 Stanley, D. J., Rehault, J. P., and Stuckenrath, R., 1980, Turbid-layer bypassing model: The

918 Corsica Trough, northwestern Mediterranean: Marine Geology, v. 37, p. 19 - 40.

919 Stuiver, M., and Reimer, P., 1993, Extended ${ }^{14} \mathrm{C}$ Data Base and Revised CALIB $3.0{ }^{14} \mathrm{C}$ Age

920 Calibration Program: Radiocarbon, v. 35, p. 215-230. doi:10.1017/S0033822200013904

921 Sweet, M. L. and Blum M. D., 2016, Connections between fluvial to shallow marine

922 environments and submarine canyons: Implications for sediment transfer to deep water:

$923 \quad$ Journal of Sedimentary Research, v. 86, p. $1147-1162$.

924 Sylvester, Z., Deptuk, M.E., Prather, B.E., Pirmez, C., and O’Byrne, C., 2012, Seismic

925 stratigraphy of a shelf-edge delta and linked submarine channels in the northeastern Gulf

926 of Mexico, in Prather, B.E., Deptuk, M.E., Mohrig, D., Van Hoorn, B., and Wynn, R. B.,

927 eds, Application of the Principles of Seismic Geomorphology to Continental-Slope and

928 Base-of-Slope Systems: Case Studies from Seafloor and Near-Seafloor Analogues: Tulsa,

$929 \quad$ SEPM, Special Publication 99, p. $31-59$.

930 Toucanne, S., Angue Minto'o, C.M., Fontanier, C., Bassetti, M.-A., Jorry, S.J., Jouet, G., 2015,

931 Tracking rainfall in the northern Mediterranean borderlands during sapropel deposition,

932 Quaternary Science Reviews, v. 129, p. 178-195. 
933 Vail, P. R. 1987, Part 1: Seismic stratigraphy interpretation procedure, in Bally, A. W., ed., Atlas

934 of Seismic Stratigraphy, Volume 1: Tulsa, American Association of Petroleum

935 Geologists Studies in Geology 27, p. $1-10$.

936 Van Wagoner, J.C., Mitchum Jr., R.M., Campion, K.M., Rahmanian, V.D., 1990, Siliciclastic

937 sequence stratigraphy in well logs, core, and outcrops: concepts for high resolution

938 correlation of time and facies, Methods in Exploration Series, v. 7: Tulsa, American

939 Association of Petroleum Geologists, 55 p.

940 Weimer, P., 1989, Sequence stratigraphy of the Mississippi Fan (Plio-Pleistocene), Gulf of

941 Mexico: GeoMarine Letters, v. 9, p. $185-272$.

942 Waelbroeck C., Labeyrie, L., Michel, E., Duplessy, J. C., McManus, J. F., Lambeck, K., Balbon,

943 E., and Labracherie, M.,2002, Sea-level and deep water temperature changes derived

944 from benthic foraminifera isotopic records: Quaternary Science Reviews, v. 21, p. 295 -

$945 \quad 305$.

946 Wintle, A. G. and A. S., Murray, 2006, A review of quartz optically stimulated luminescence

947 characteristics and their relevance in single-aliquot regenerative protocols: Radiation

948 Measurements, v. 41, p. 369-391.

949 
951 Figure 1. Elevation map of Corsica (ASTER V2 GDEM 30m resolution) and bathymetry of the

952 Corsica Basin (TCarta's bathymetric grid derived from 1:2000, 000 scale charts and 1:60,000

953 scale coastline from Landsat imagery at $90 \mathrm{~m}$ seafloor resolution) showing the study area (white

954 box), location of the modern Golo fans and the Golo River drainage basin. Contours of

955 submarine channels and lobes modified from Figure IV-28 in Gervais (2002). Imagery licensed

956 by agreement with Spatial Energy (lb@SpatialEnergy.com).

957 Figure 2. Map of multi-beam bathymetry from the 2008 SIGOLO survey, $10 \mathrm{~m}$ resolution; $25 \mathrm{~m}$

958 grid spacing. Water depth in meters. In addition to bathymetry this map shows the location of the

959 seismic lines (in white) acquired in the 2008 SIGOLO survey and the GDEC cores cut in 2009

960 coring campaign. SGC - South Golo Canyon. NGC - North Golo Canyon. Contour Interval $=10$

$961 \mathrm{~m}$. The location of seismic lines used in the figures are numbered by figure and shown with

962 heavier dark lines.

963 Figure 3. Seismic line Sigolo-081 showing geometries and facies used to construct the seismic

964 stratigraphic framework. Seismic facies are High Amplitude Semi-Continuous (HASC) and High

965 Amplitude Continuous (HAC). Core data indicate that HASC facies are sand-rich, while HAC

966 are mud-rich with interbedded marls. Sequence boundaries (SB) are shown as solid lines. They

967 are characterized by incision/truncation and downlap/onlap (arrows). Flooding surfaces (FS) are

968 shown as dashed lines. They are characterized by draping geometries and very high continuity of

969 seismic events. V.E. $=$ X15.

970 Figure 4. Seismic line Sigolo-034b showing the geometry of the Golo shelf, slope and underlying

971 deposits. Grain size of the GDEC-1 and GDEC-3 cores (green $=$ silt and clay, yellow $=$ sand,

972 orange $=$ gravel $)$ and their tie to seismic data are also shown. V.E. $=$ X8. 
973 Figure 5. Cross-section showing the 5 cores cut for this study, their lithologies, ages and 974 stratigraphic relations. Core depths are in meters below seafloor. Age data in years from ${ }^{14} \mathrm{C}$ 975 (black), OSL (red) and $\delta^{18} \mathrm{O}$ (green) are shown. Marls shown in blue, sequence boundaries in red 976 and flooding surfaces in green are correlated using seismic and age data.

977 Figure 6. Seismic line Sigolo-085 across the Corsica slope crossing the location of the GDEC-4 978 core with median grain size (D50) and calcimetry logs shown to calibrate seismic facies. 979 Lowstand systems tract deposits (e.g. G1100 etc.) are shown bounded at the base by sequence 980 boundaries in red (e.g. $1100 \mathrm{SB}$ etc.) and top by flooding surfaces in green (e.g. 1100 FS etc.). $981 \quad$ V.E. $=$ X7.

982 Figure 7. Seismic line Sigolo-058 on the South Golo Fan showing the location of the GDEC-6 983 core with median grain size (D50) and calcimetry logs shown to calibrate seismic facies. 984 Location of marly intervals interpreted on cores are highlighted in blue. Lowstand systems tract 985 deposits (e.g. G1100 etc.) are shown bounded at the base by sequence boundaries in red (e.g. $9861100 \mathrm{SB}$ etc.) and top by flooding surfaces in green (e.g. $1100 \mathrm{FS}$ etc.). The $1300 \mathrm{SB}$ is an 987 internal surface within the 1100 sequence that records base of an MIS-4 fan. V.E. $=$ X7.

988 Figure 8. Seismic line Sigolo-007 on the South Golo Channel showing the location of the 989 GDEC-8 core with median grain size (D50) and calcimetry logs shown to calibrate seismic 990 facies. Lowstand systems tract deposits (e.g. G1100 etc.) are shown bounded at the base by 991 sequence boundaries in red (e.g. $1100 \mathrm{SB}$ etc.) and top by flooding surfaces in green (e.g. 1100 992 FS etc.). V.E. $=$ X7.

993 Figure 9. Oxygen isotope curves from benthic foraminifera sampled in the GDEC-4, 6, and 8 994 cores compared to the global standard of Lisiecki and Raymo (2005). Ages are labelled on the 
995 vertical axis of the Lisiecki and Raymo (2005) curve while the curves from the GDEC cores are 996 plotted in depth (mbsf) with interpreted oxygen isotope stages shown.

997 Figure 10. Age model for the Corsica Trough. The upper panel shows the depths of age 998 measurements from OSL and ${ }^{14} \mathrm{C}$ and age estimates from $\delta^{18} \mathrm{O}$ curves from the GDEC 4,6 , and 8 999 cores. Age estimates for lowstand systems tract deposits are show in the colored boxes. The 1000 lower panel shows composite mean sea level curve (thick gray line) after Waelbroeck et al. 1001 (2002) plotted along with Shackleton's (2000) mean water $\delta^{18} \mathrm{O}$ curve (dotted blue line). Marine 1002 Oxygen Isotope Stages are also shown on the sea level (bold, black numbers). Lowstand systems 1003 tract deposits are shown in colors, highstand systems tract deposits are in white.

1004 Figure 11. Isopach maps of 5 lowstand systems tracts interpreted in this study. Note that 1005 individual submarine fans are associated with either the north or south Golo Canyons. Dashed 1006 red lines show the interpreted direction of sediment transport.

1007 Figure 12. Shaded bathymetry of the Corsica shelf, slope, and trough showing the location of the 1008 North (NGC) and South Golo canyons (SGC), South Golo Fan (SGF), Fuim Alto Gulley (FG), 1009 Pineto Gulley (PG), cores used in this study (GDEC-1 etc.), the LGM shoreline at -120 m and 1010 lobe-shaped bathymetric features interpreted as relict deltaic lobes. Seismic line A-A' illustrates 1011 a deltaic lobe with clinoforms (DC) that impinged on the edge of the South Golo Canyon when 1012 sea level was about $-80 \mathrm{~m}$ below current sea level and the delta fed sediment directly into the 1013 canyon.

1014 Figure 13. Bathymetric map showing the location of two seismic lines (A - A' and B - B'), the 1015 updip extent of the South Golo Canyon beneath the modern shelf (solid black lines) and the 1016 extent of the larger MIS-2 paleo-valley (thick, gray cross-hatched lines on the shelf). A) Seismic 1017 line Sigolo-067 illustrates the updip extent of the South Golo Canyon where is has merged with 
1018 the MIS-4 (1100 SB) paleo-valley of the Golo River. B) Seismic line Sigolo-021 in the lower

1019 reaches of the South Golo Canyon illustrates the cross-sectional shape of the canyon and the

1020 aggradational nature of deposits adjacent to the canyon. High amplitude discontinuous seismic

1021 facies (HDC) interpreted as a coarse sand and gravel are restricted to the deepest part of the

1022 canyon and also show aggradational stacking.

1023

1024 Figure 14. Shaded bathymetry of the Corsica shelf and slope showing location of the shoreline 1025 from 1100 SB (MIS-4) to the 1600 surface (Younger Dryas) in relation to the North and South 1026 Golo canyons.

1027 Figure 15. Seismic lines: A) Sigolo-086; B) Sigolo-07; and C) Sigolo-51 showing down-channel 1028 changes in levee height and geometry along the South Golo channel. V.E. = X 5. Location map 1029 shows bathymetry in meters $($ C.I. $=25 \mathrm{~m})$ and the location of the seismic lines.

1030 Figure 16. Bathymetric map showing the distribution of lobate bodies attached to channel-levee 1031 systems and gullies throughout the basin that were deposited during MIS-2 and MIS-4. Seismic 1032 lines $\mathrm{A}$ and $\mathrm{B}$ show lobe geometries associated with a fan fed by the North Golo Canyon. 1033 Seismic lines C (Sigolo-058) and D (Sigolo-004) show strike (C) and dip (D) profiles across the 1034 most recent South Golo lobe complex revealing the internal geometries of small-scale lobes and 1035 lobe elements. HAD - High-Amplitude Discontinuous seismic facies, HAC - High-Amplitude 1036 Continuous seismic facies, LAC - Low-Amplitude Continuous seismic facies. V. E. = X 15.

1037 Figure 17. Schematic representation of the hierarchy of channel-form and distributive lobe 1038 bodies observed in the South Golo Canyon (Fairway) and at the mouth of its channel. The grain 1039 size log from core GEC-6 gives a vertical representation of the lithology of the lobe hierarchy. 


\section{TABLE CAPTIONS}

1041 Table 1. Location, length, and sediment recovery of cores used in this study.

1042 Table 2. Sediment volumes, estimated time of deposition and sedimentation rates for the

1043 lowstand systems tract deposit (LS1100, LS1000, etc.) and intervening mud-rich transgressive 1044 and highstand systems tract deposits (TH1100, TH1000 etc.) mapped in the study area. Sand 1045 percent was estimated from core and seismic facies data.

1046

1047 


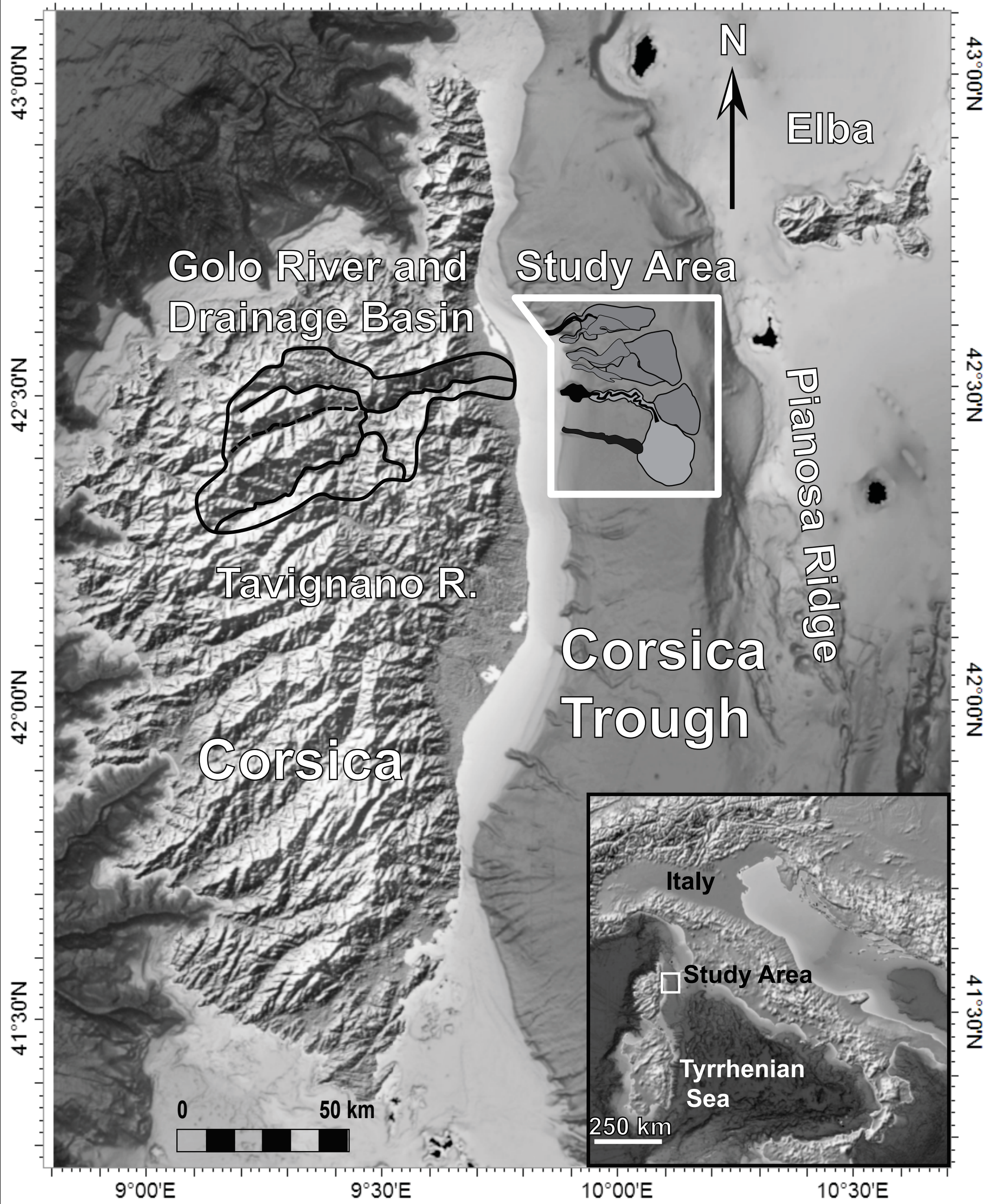


Figure 2

$9^{\circ} 36^{\prime} \mathrm{E}$ $9^{\circ} 48^{\prime} \mathrm{E}$

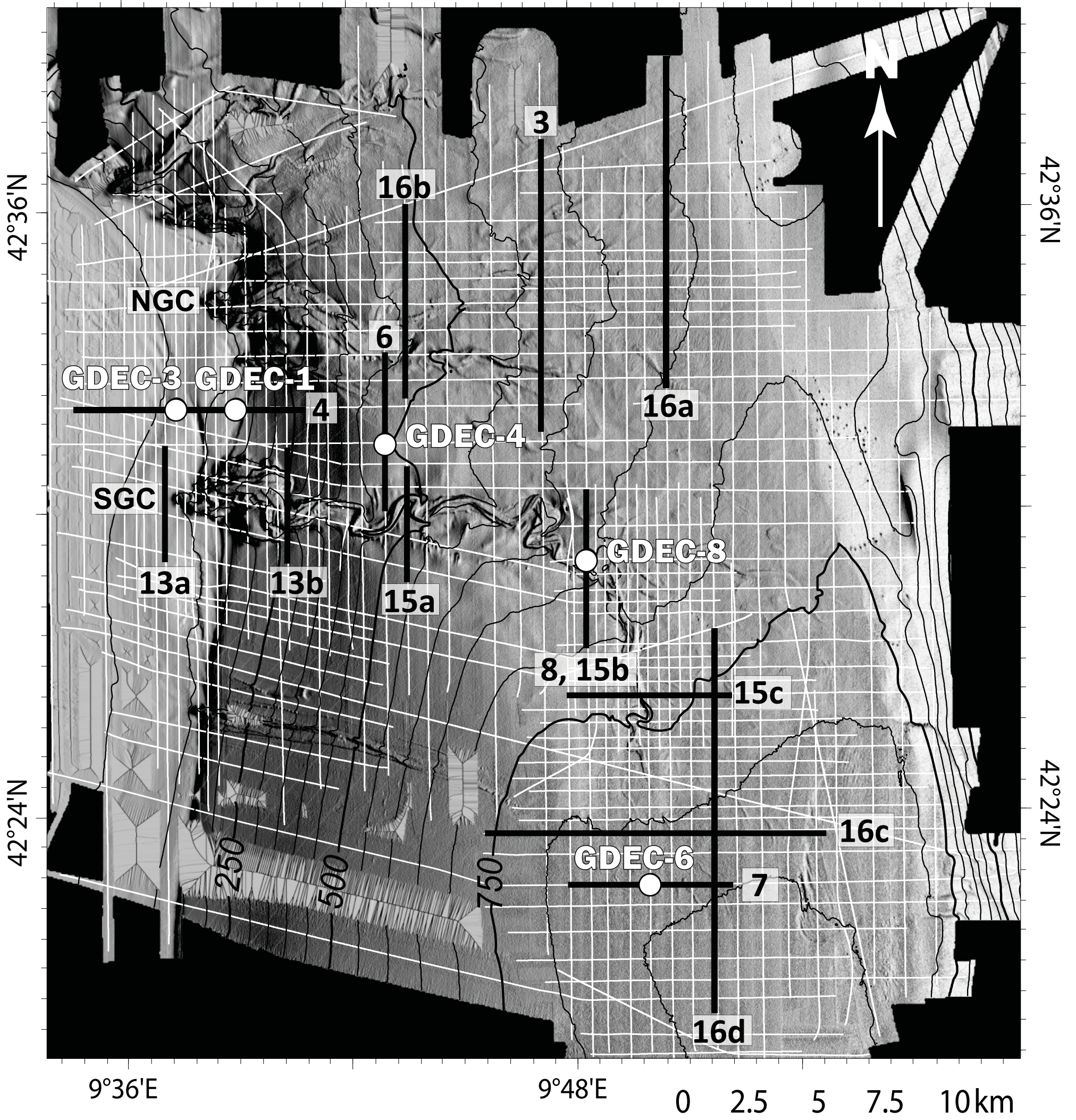




\section{Figure 3}

\section{Sweet et al. Figure 3}

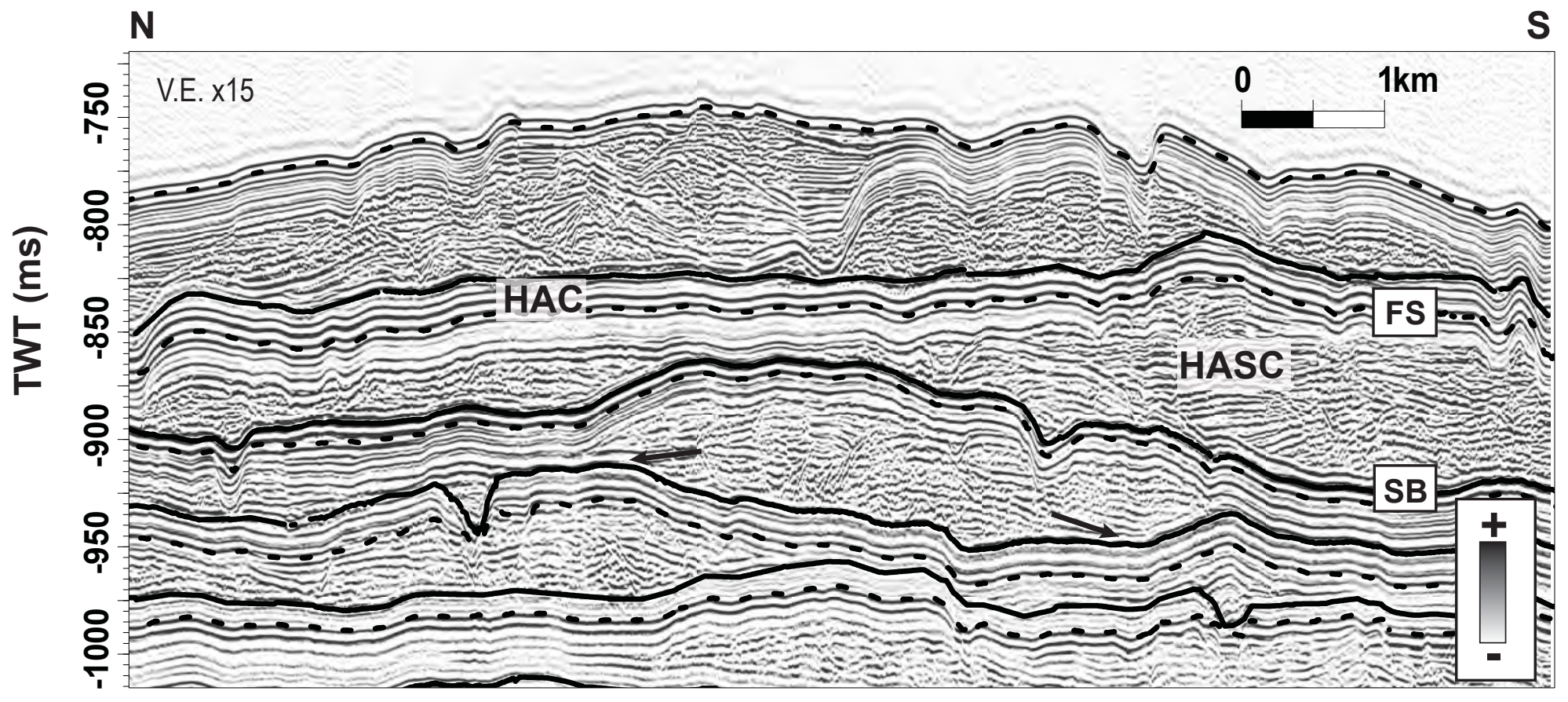




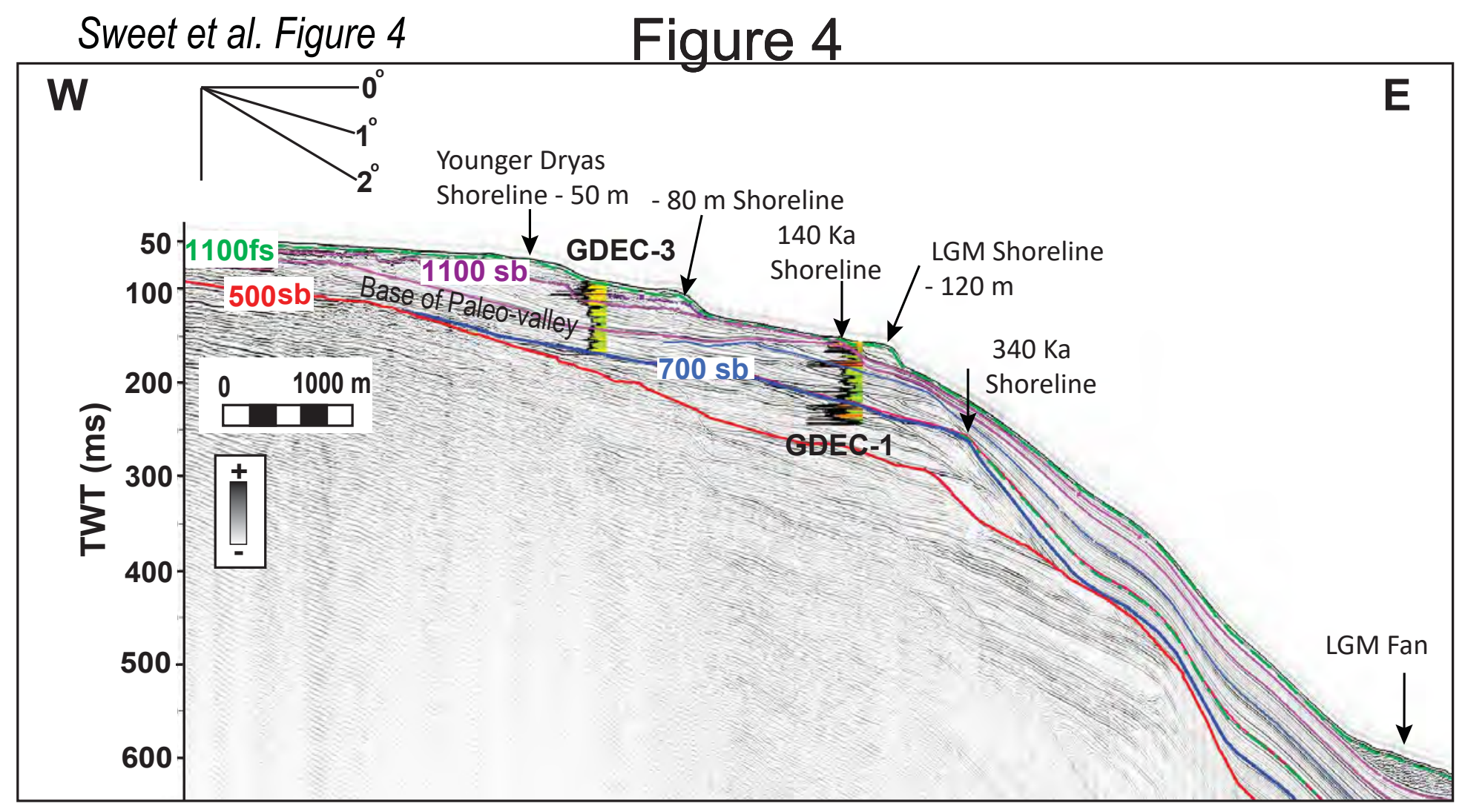


Sweet et al. Figure 6

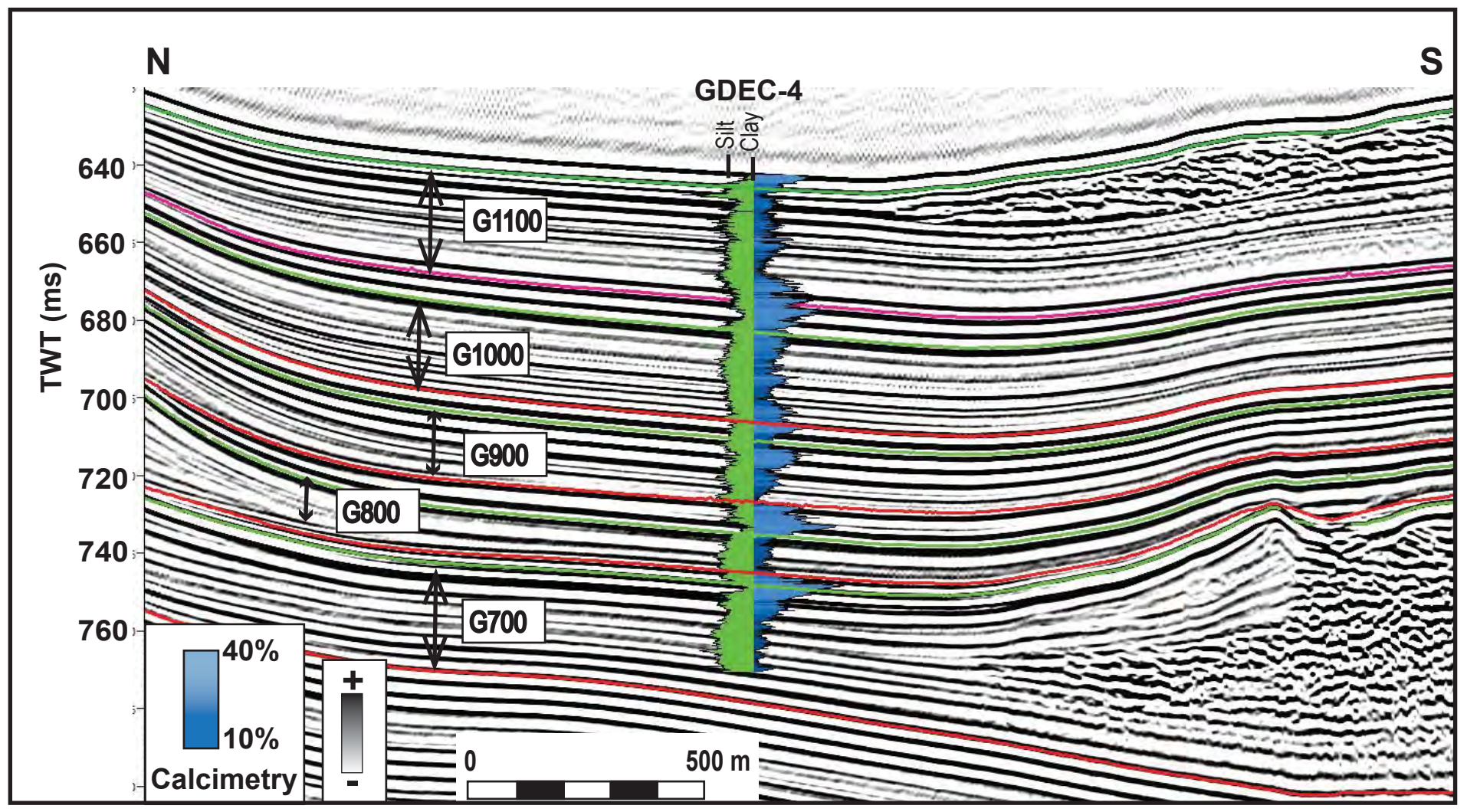


Sweet et al. Figure 7

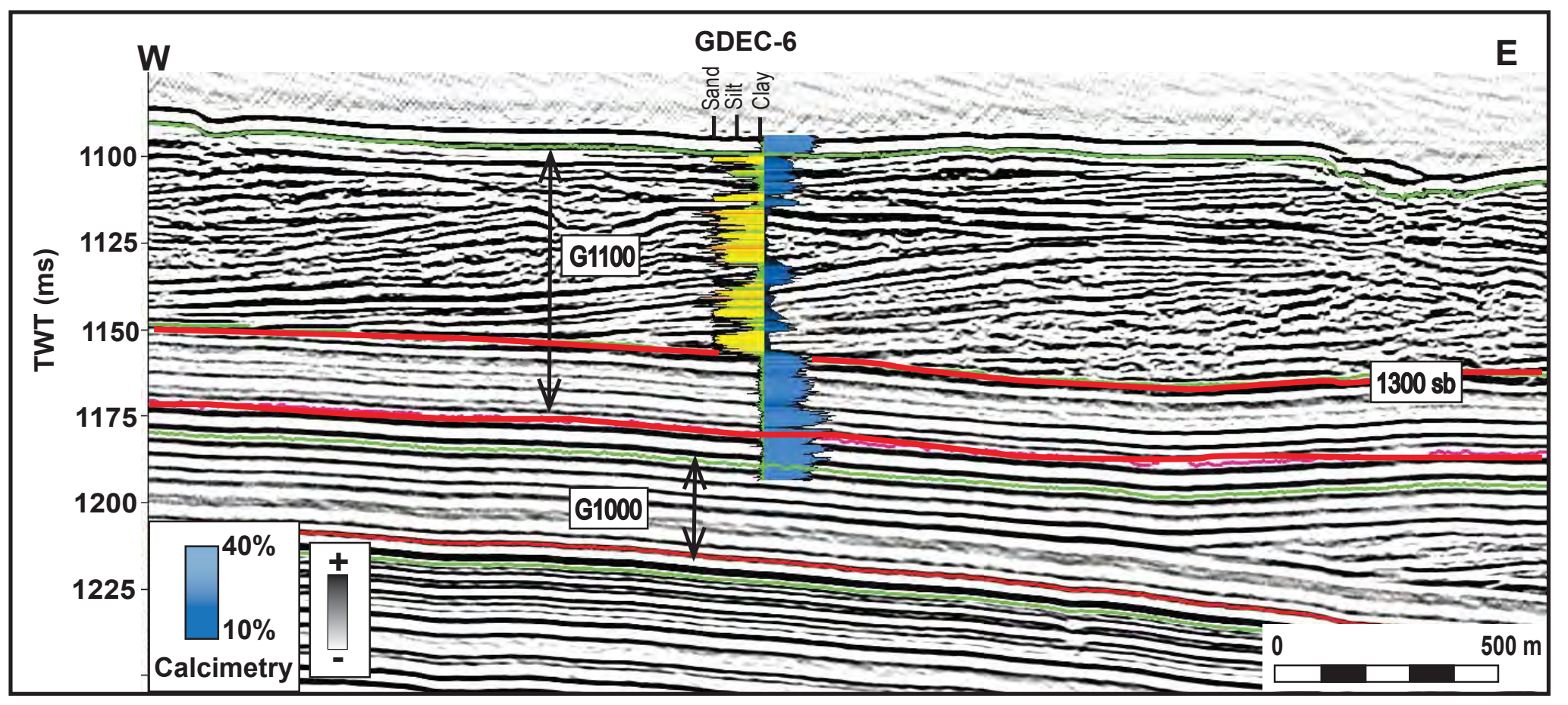


Sweet et al. Figure 8

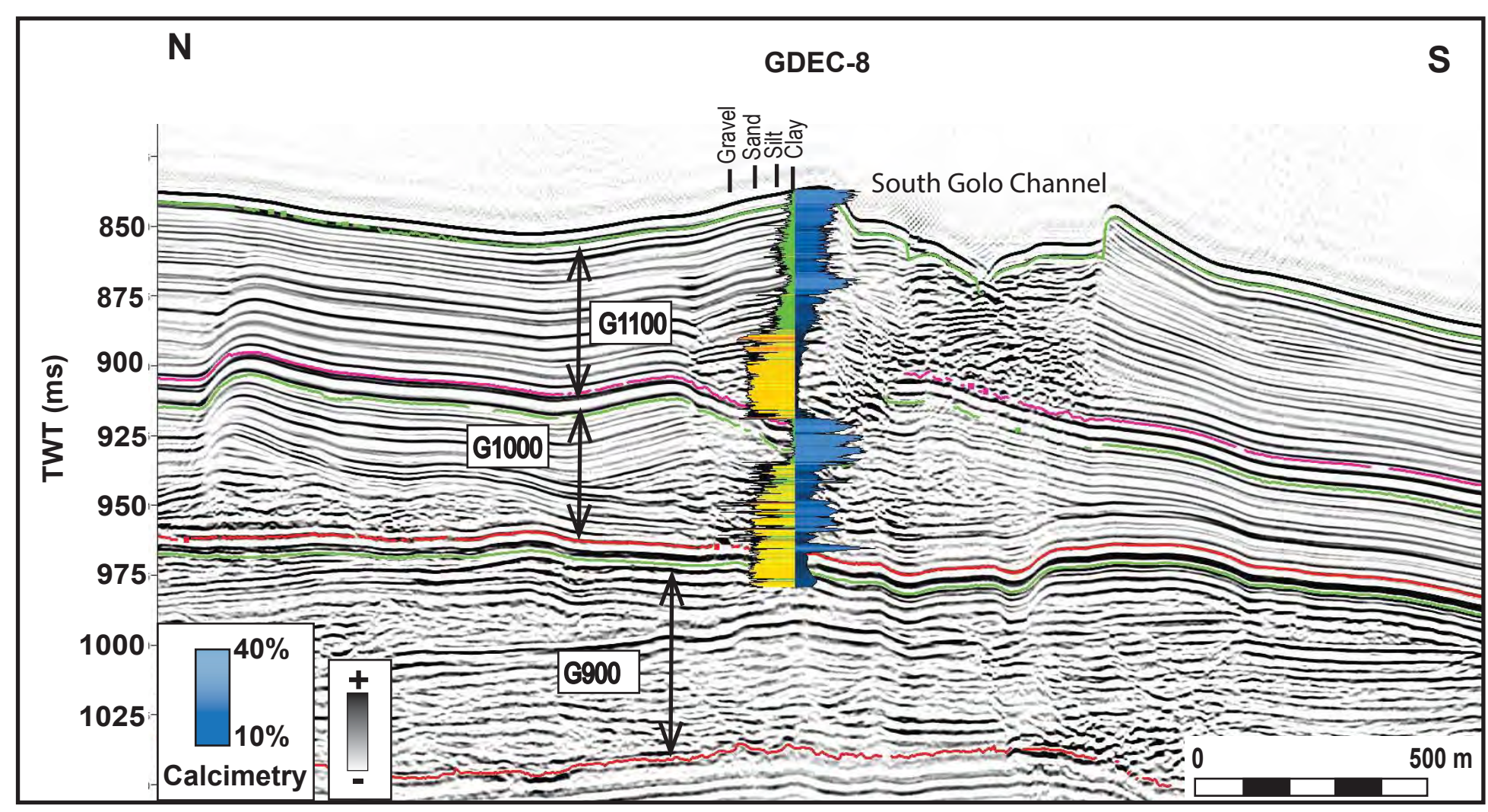


Sweet et al. Figure 9

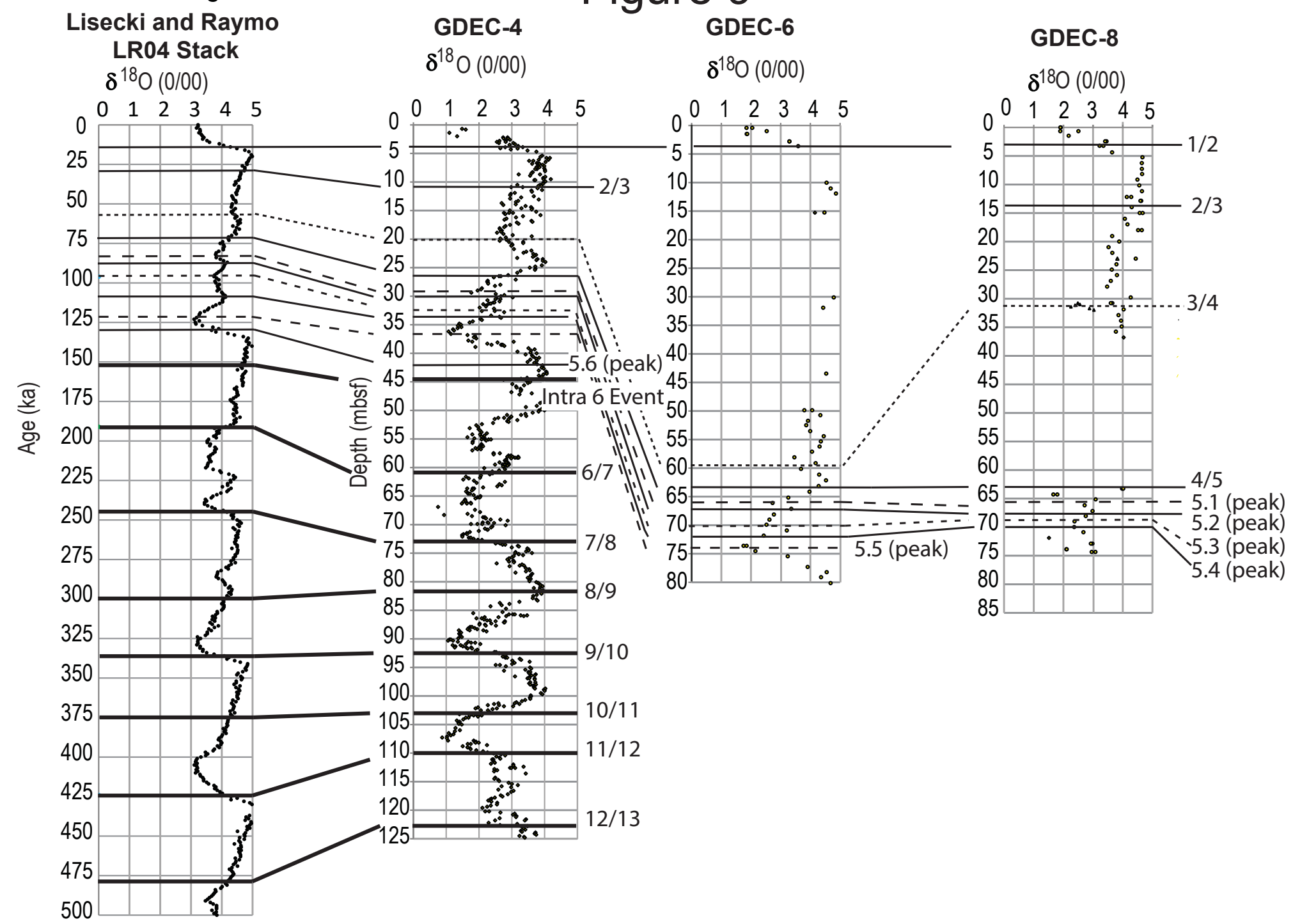


Sweet et al. Figure 10

Figure 10
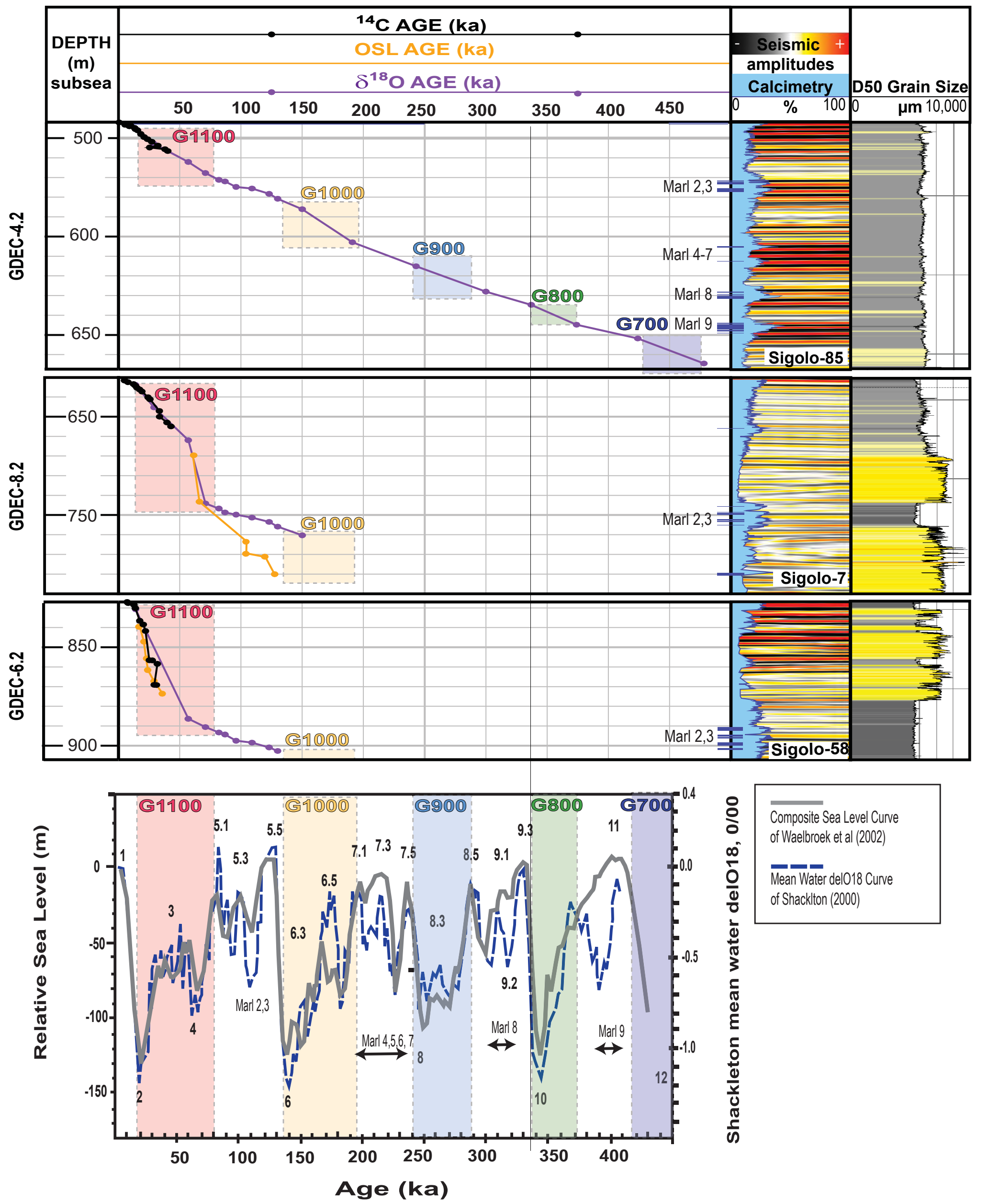

Composite Sea Level Curve of Waelbroek et al (2002)

Mean Water del018 Curve of Shacklton (2000) 
G1100 Sequence (MIS-4 and 2) Fans

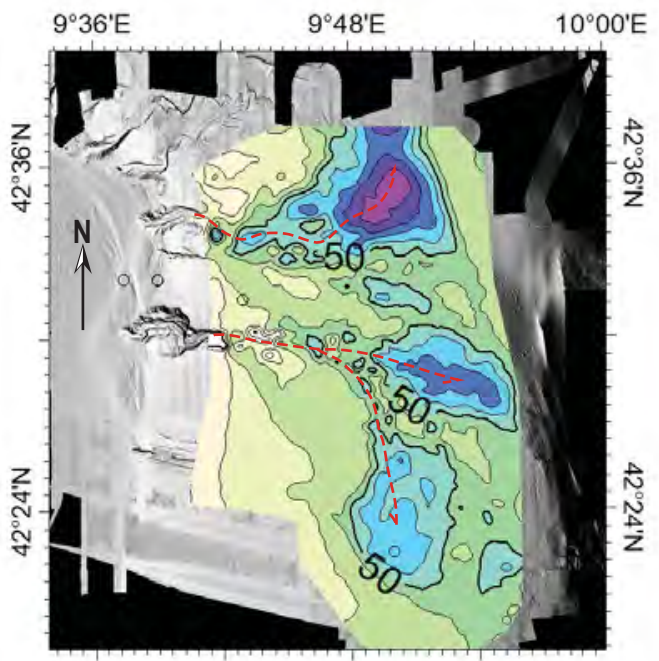

G800 Sequence (MIS-10) Fans

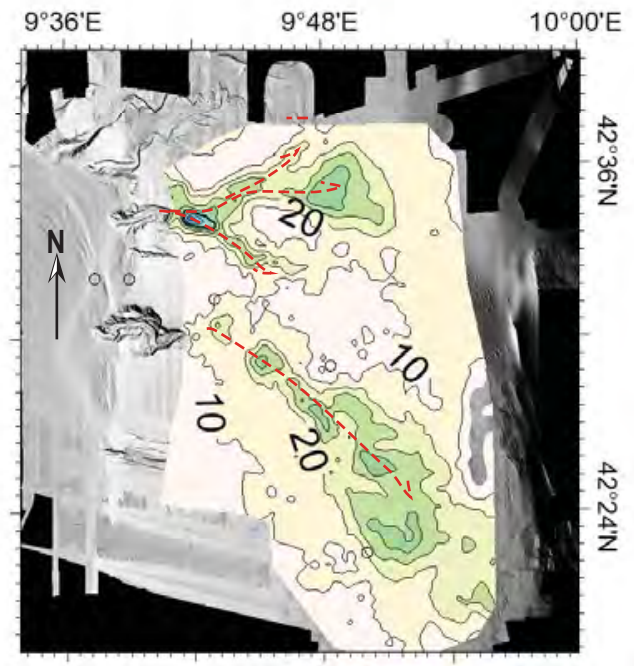

Figure 11

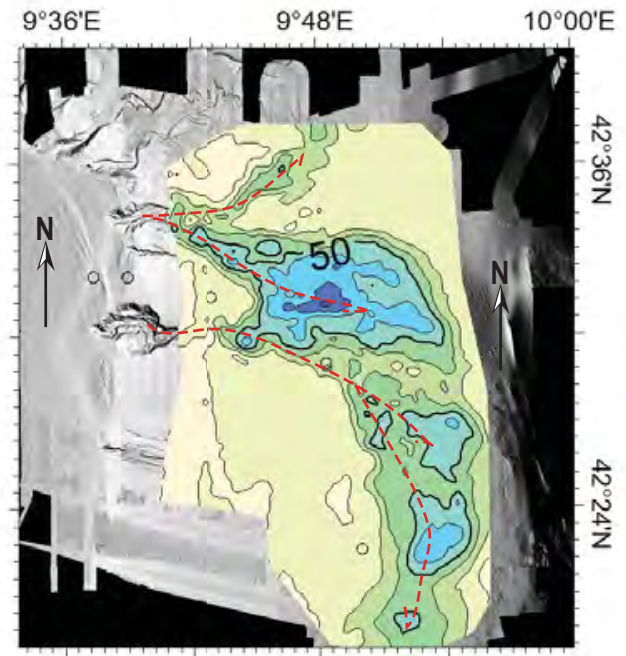

G700 Sequence (MIS-12) Fans

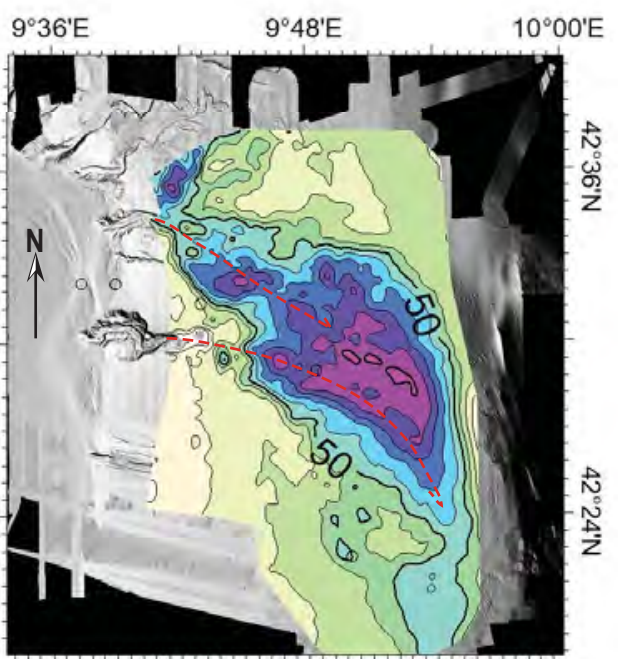

G900 Sequence (MIS-8) Fans
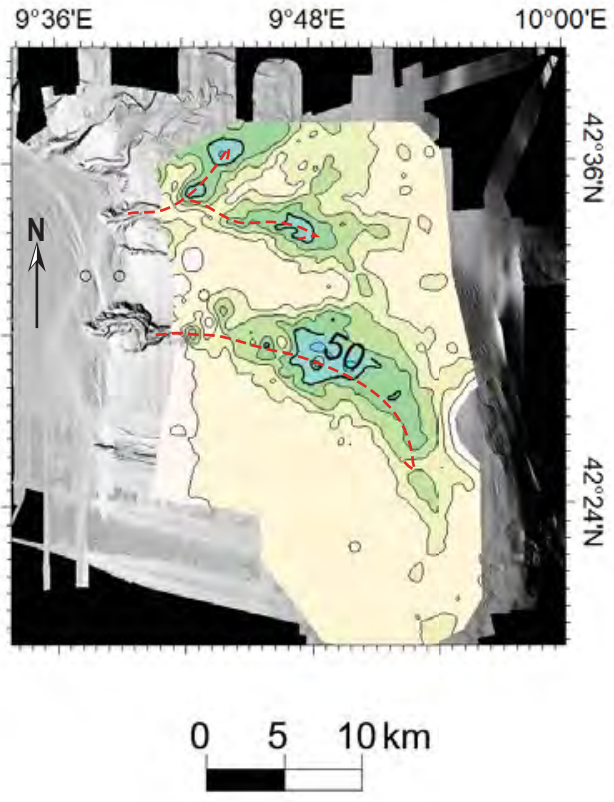

Thickness (m)

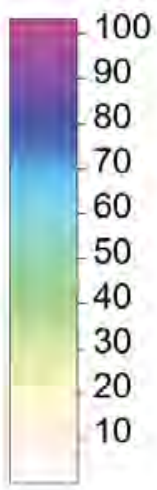


Sweet et al. Figure 12
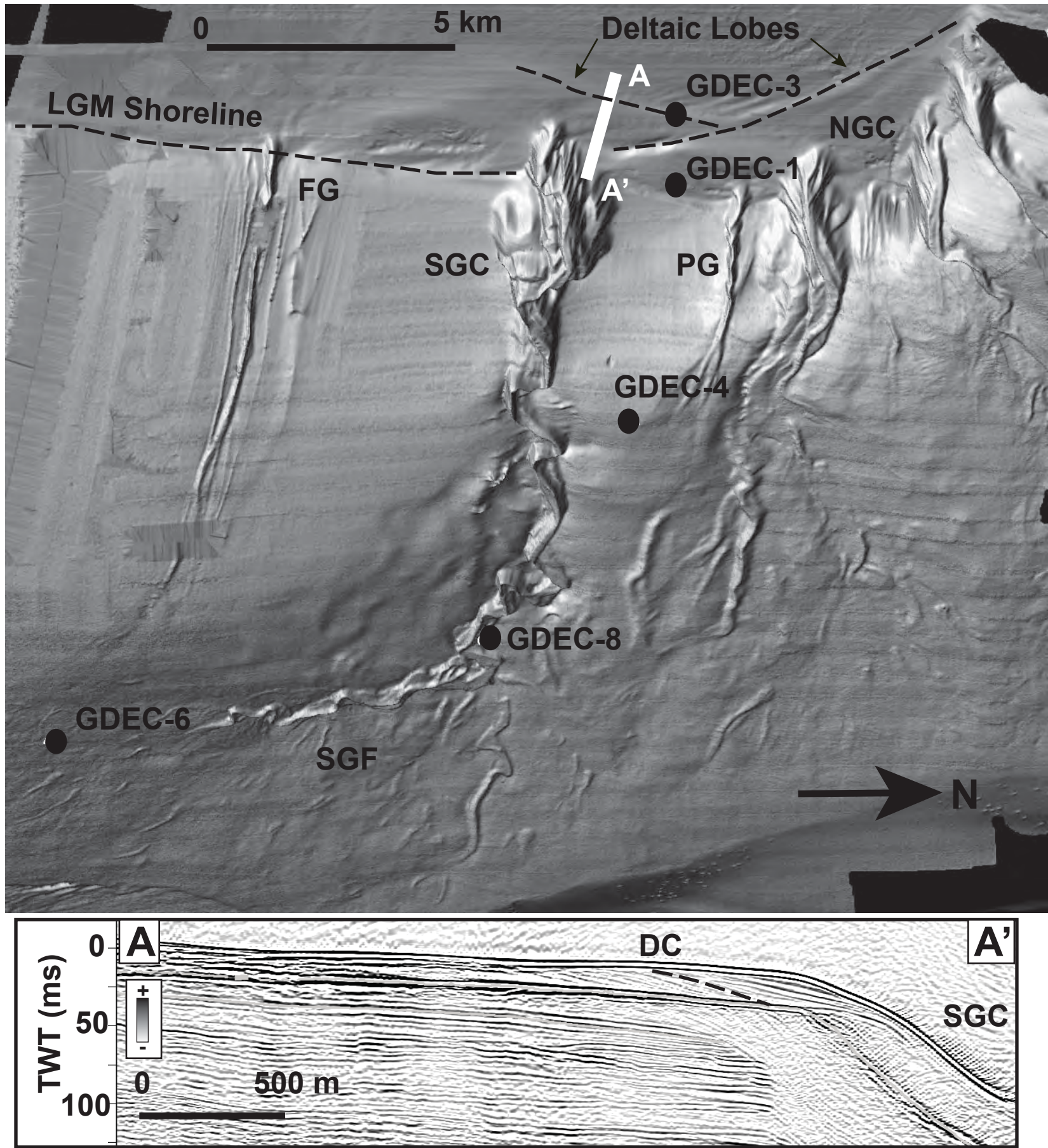
Sweet et al. Figure 13
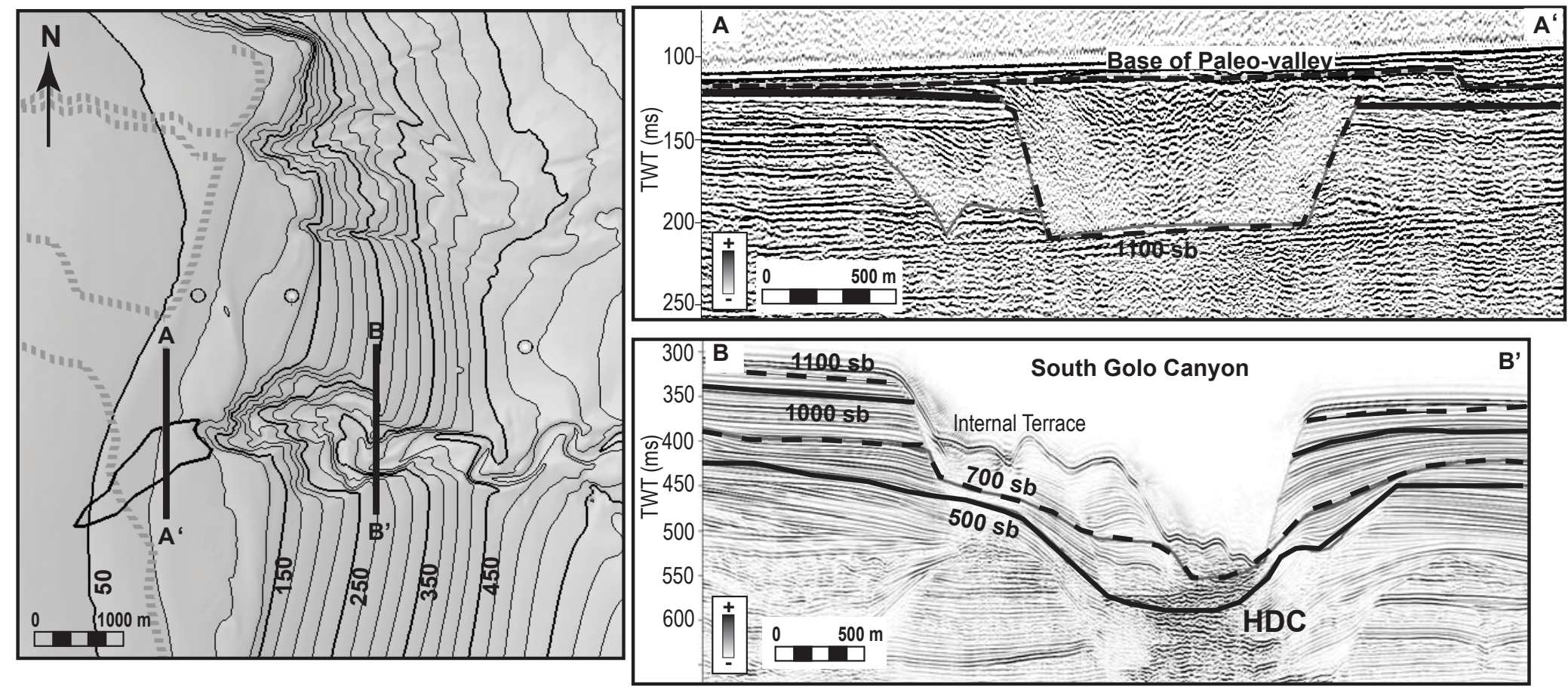
Sweet et al. Figure 14
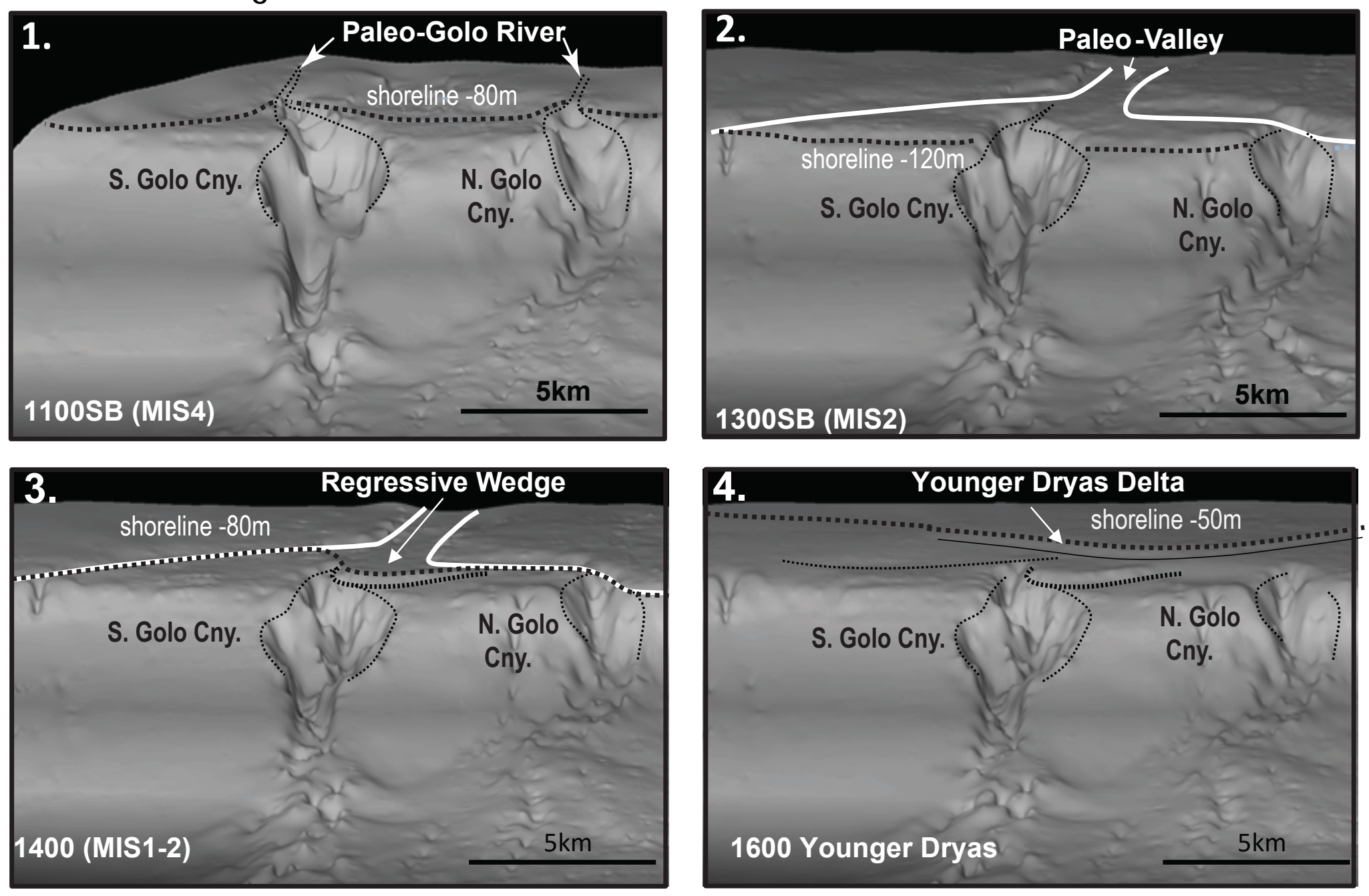


\section{Sweet et al. Figure 15}
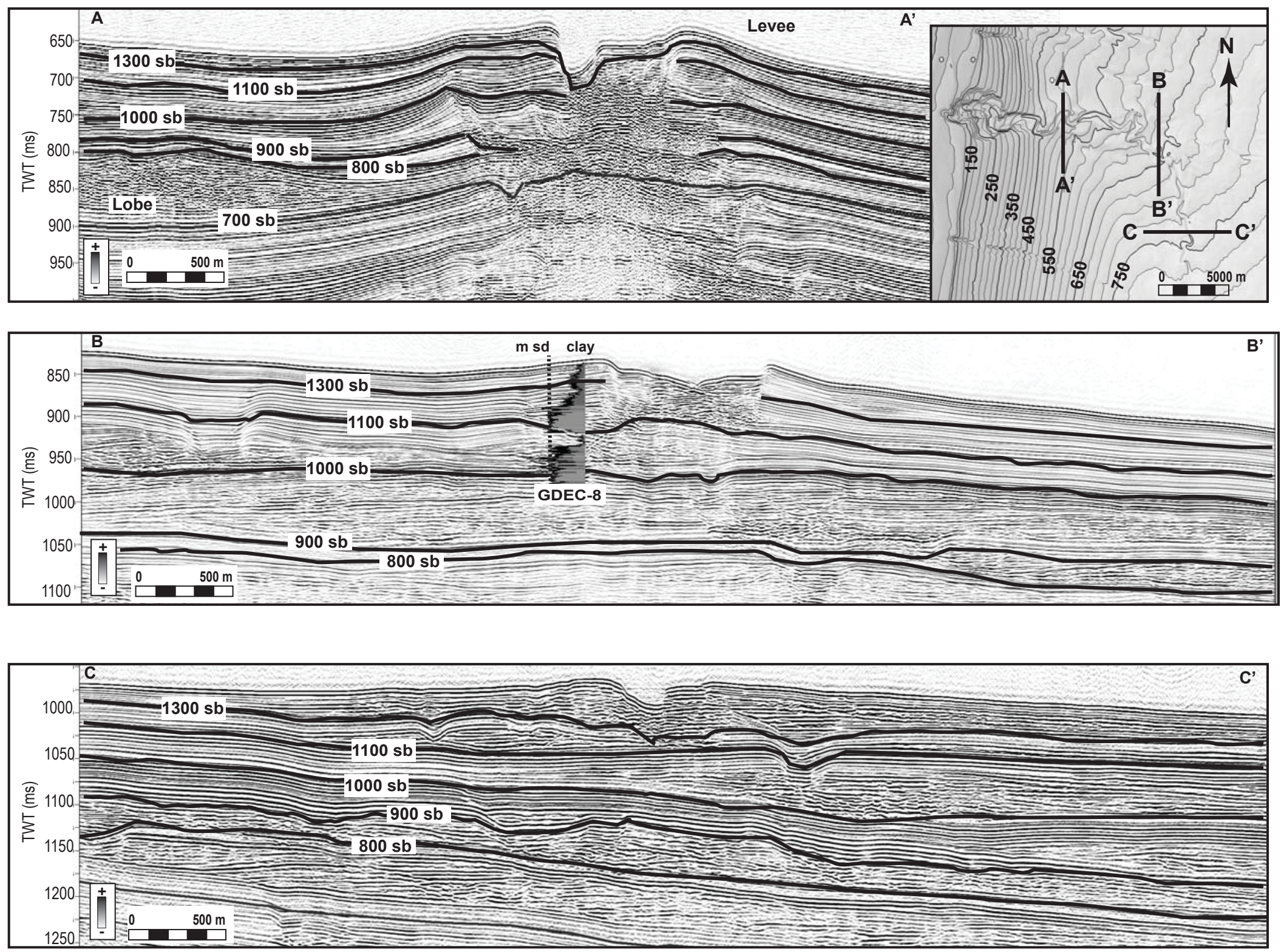

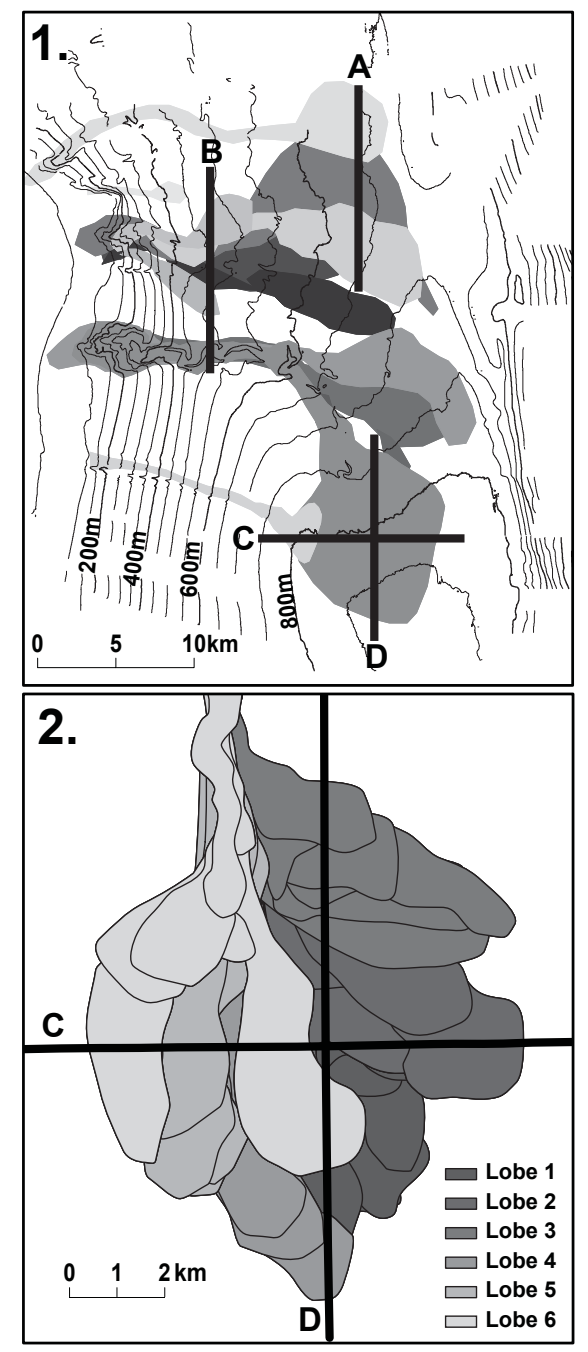

Figure 16
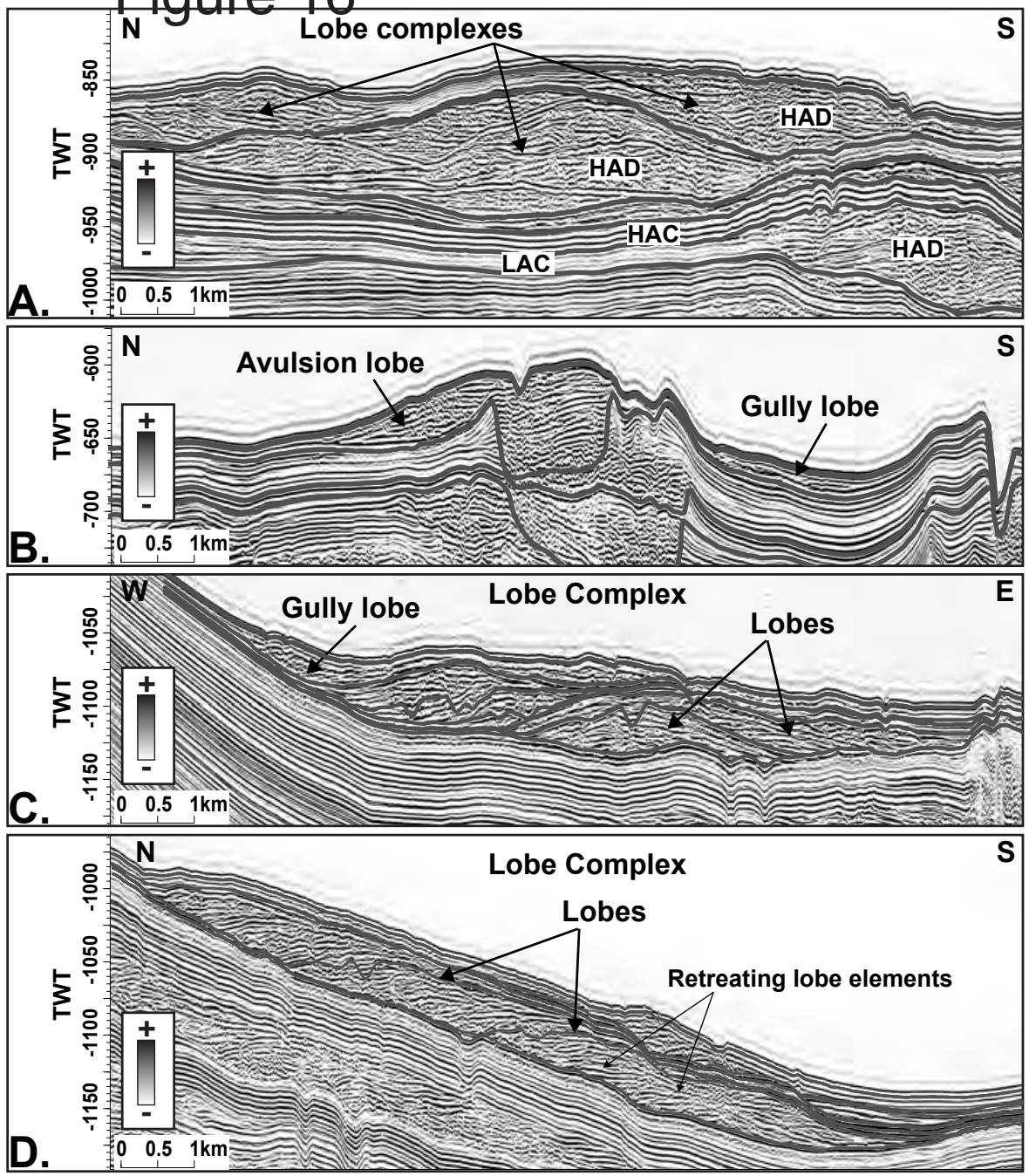
Fairway

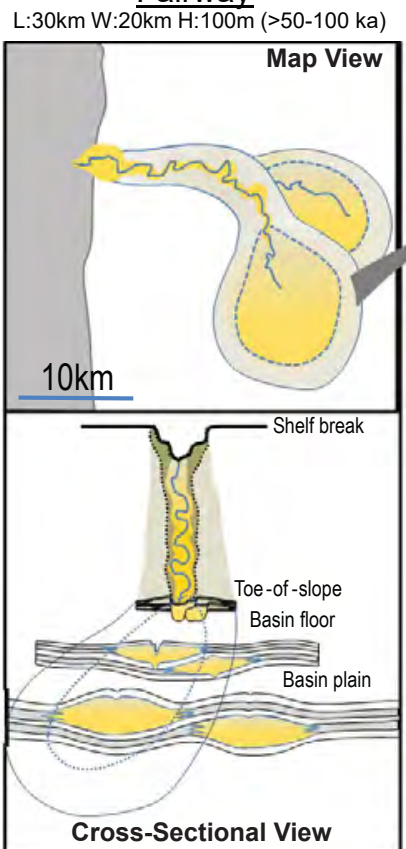

Lobe complex

L:12km W:10km H:50m (10-20 ka)

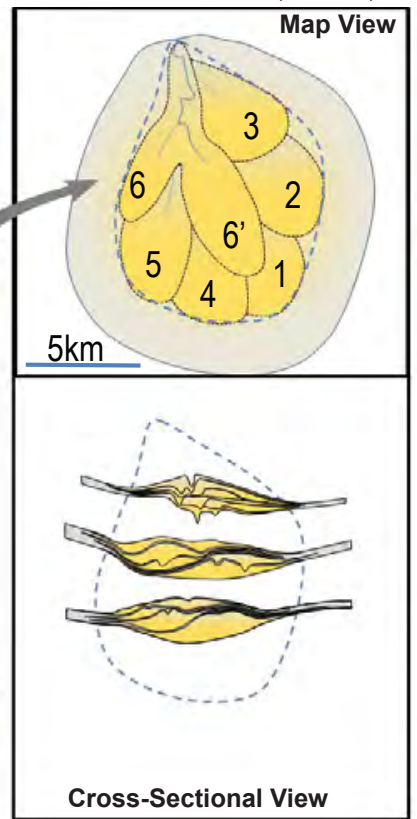

Lobes

L:10km W:5km H:25m (1-3 ka)

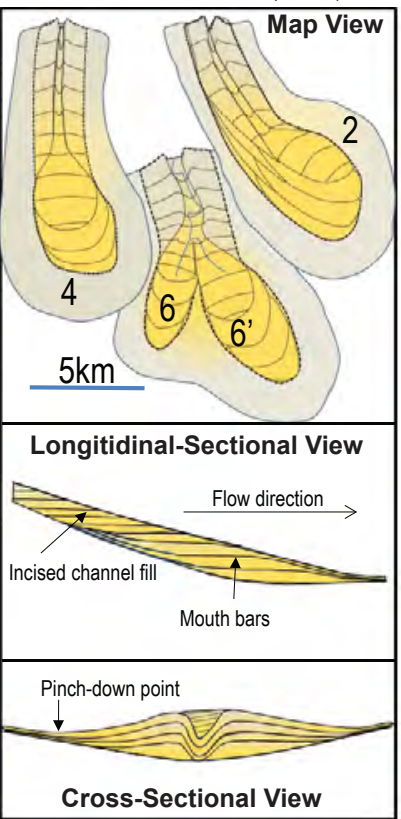

Lobe element

L:8km W:3km H:5-15m (0.5-1.5 ka)

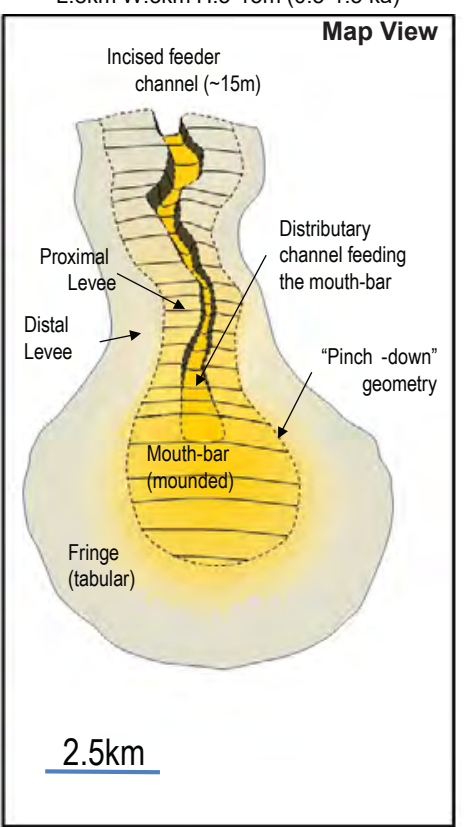

Bed to Bed sets

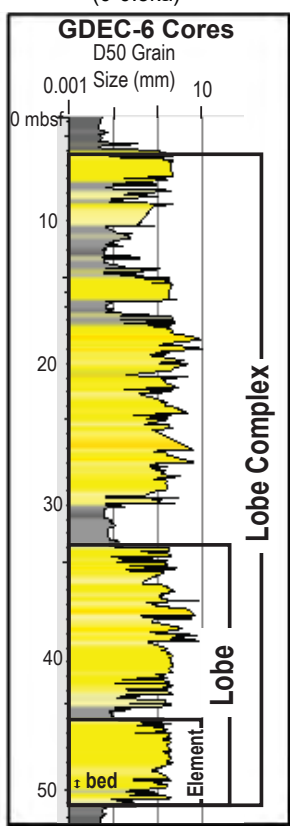




\begin{tabular}{|c|c|c|c|c|c|c|}
\hline Well & Location & $\begin{array}{c}\text { Water } \\
\text { Depth } \\
(\mathrm{m})\end{array}$ & $\begin{array}{c}\text { Total } \\
\text { Cored } \\
\text { Depth } \\
\text { (mbsf) }\end{array}$ & $\begin{array}{c}\text { Recovery } \\
(\%)\end{array}$ & Latitude (N) & Longitude (E) \\
\hline GDEC-1 & Shelf & 116 & 75.2 & 91 & $42^{\circ} 32^{\prime} 05.741$ & $9^{\circ} 38^{\prime} 59.990$ \\
GDEC-3 & Shelf & 68 & 64.8 & 91 & $42^{\circ} 32^{\prime} 06.661$ & $9^{\circ} 37^{\prime} 23.827$ \\
GDEC-4 & Slope & 491 & 125.7 & 93 & $42^{\circ} 31^{\prime} 23.243$ & $9^{\circ} 42^{\prime} 06.661$ \\
GDEC-6 & Fan & 826 & 80.2 & 75 & $42^{\circ} 22^{\prime} 34.876$ & $9^{\circ} 49^{\prime} 59.770$ \\
GDEC-8 & Levee & 631 & 108.8 & 88 & $42^{\circ} 29^{\prime} 03.173$ & $9^{\circ} 48^{\prime} 23.212$ \\
\hline
\end{tabular}




\begin{tabular}{|c|c|c|c|c|c|c|c|c|c|}
\hline Interval & Area $\left(\mathrm{m}^{2}\right)$ & Sand $(\%)$ & $\begin{array}{c}\text { Total } \\
\text { Volume }\left(\mathrm{m}^{3}\right)\end{array}$ & $\begin{array}{c}\text { Sediment } \\
\text { Volume }\left(\mathrm{m}^{3}\right) \\
(\text { assumes } 30 \% \\
\text { porosity) }\end{array}$ & $\begin{array}{c}\text { Duration } \\
(\mathrm{ka})\end{array}$ & $\begin{array}{c}\text { Average } \\
\text { Thickness } \\
(\mathrm{m})\end{array}$ & $\begin{array}{c}\text { Total } \\
\text { Rate } \\
(\mathrm{m} / \mathrm{ka})\end{array}$ & $\begin{array}{c}\text { Sand Rate } \\
(\mathrm{m} / \mathrm{ka})\end{array}$ & $\begin{array}{c}\text { Mud Rate } \\
(\mathrm{m} / \mathrm{ka})\end{array}$ \\
\hline \hline TH1100 & $5.87 \mathrm{E}+08$ & 0 & $1.92 \mathrm{E}+09$ & $1.35 \mathrm{E}+09$ & $0-14$ & 2.29 & 0.16 & 0.00 & 0.16 \\
\hline LS1100 & $5.87 \mathrm{E}+08$ & 69 & $2.54 \mathrm{E}+10$ & $1.78 \mathrm{E}+10$ & $14-87$ & 30.29 & 0.41 & 0.29 & 0.13 \\
\hline TH1000 & $5.87 \mathrm{E}+08$ & 0 & $4.37 \mathrm{E}+09$ & $3.06 \mathrm{E}+09$ & $87-135$ & 5.21 & 0.11 & 0.00 & 0.11 \\
\hline LS1000 & $5.87 \mathrm{E}+08$ & 63 & $1.91 \mathrm{E}+10$ & $1.34 \mathrm{E}+10$ & $135-190$ & 22.78 & 0.35 & 0.22 & 0.13 \\
\hline TH900 & $5.87 \mathrm{E}+08$ & 0 & $2.87 \mathrm{E}+09$ & $2.01 \mathrm{E}+09$ & $190-240$ & 3.42 & 0.07 & 0.00 & 0.07 \\
\hline LS900 & $5.87 \mathrm{E}+08$ & 47 & $1.98 \mathrm{E}+10$ & $1.38 \mathrm{E}+10$ & $240-290$ & 23.57 & 0.59 & 0.28 & 0.31 \\
\hline TH800 & $5.87 \mathrm{E}+08$ & 0 & $7.07 \mathrm{E}+09$ & $4.95 \mathrm{E}+09$ & $290-340$ & 8.44 & 0.17 & 0.00 & 0.17 \\
\hline LS800 & $5.87 \mathrm{E}+08$ & 50 & $1.00 \mathrm{E}+10$ & $7.03 \mathrm{E}+09$ & $340-375$ & 11.97 & 0.34 & 0.17 & 0.17 \\
\hline TH700 & $5.87 \mathrm{E}+08$ & 0 & $4.09 \mathrm{E}+09$ & $2.86 \mathrm{E}+09$ & $375-415$ & 4.87 & 0.19 & 0.00 & 0.19 \\
\hline
\end{tabular}

